\title{
A CARTOGRAFIA GEOMORFOLÓGICA EM ESCALA REGIONAL: O CASO DA REGIÃO METROPOLITANA DA BAIXADA SANTISTA -SP
}

\author{
André dos Santos Ribeiro \\ Doutorando em Geografia, Instituto de Geociências, Universidade Estadual de Campinas (UNICAMP), \\ Campinas, SP, Brasil \\ andre.santosribeiro@yahoo.com.br \\ Regina Célia de Oliveira \\ Professora Doutora, Instituto de Geociências, Universidade Estadual de Campinas (UNICAMP) \\ Campinas, SP, Brasil \\ regina5@unicamp.br
}

\begin{abstract}
RESUMO
A cartografia geomorfológica é instrumento importante para a Geomorfologia, para as Ciências da Terra em geral e para o planejamento da paisagem uma vez que define a leitura, interpretação e espacialização das formas de relevo e processos morfodinâmicos, partindo do emprego de metodologias e uso de simbologias específicas atendendo diferentes taxonomias. Considerando isto, foram aplicadas as proposições do Manual Técnico de Geomorfologia (IBGE, 2009) voltado à cartografia regional com os procedimentos organizados em níveis, conforme Libault (1971), enfocando discutir o processo de interpretação, classificação e representação, demanda relevante para a cartografia geomorfológica, no estudo de caso da Região Metropolitana da Baixada Santista em escala 1:100.000. Ao longo da interpretação a contextualização da evolução das formas de relevo e a toponímia sobressaíram como elementos-chave para determinação da identidade das unidades geomorfológicas, como pressupõe a técnica adotada. Também ficou esclarecido que ao longo da interpretação há integração entre as classificações e as delimitações espaciais de formas identificadas em diferentes táxons. A partir de algumas generalizações e agrupamentos do que foi interpretado, impostas pela escala e acuidade visual no mapa, a geomorfologia regional foi representada e caracterizada, sobretudo as unidades geomorfológicas e as formas predominantes de relevo.
\end{abstract}

Palavras-chave: Manual Técnico de Geomorfologia. Unidades geomorfológicas. Interpretação do relevo. Geomorfologia costeira. Níveis da pesquisa geográfica.

\section{GEOMORPHOLOGICAL MAPPING IN REGIONAL SCALE: THE CASE OF THE BAIXADA SANTISTA METROPOLITAN REGION, SÃO PAULO - BRAZIL}

\begin{abstract}
Geomorphological mapping is an important instrument for Geomorphology, for earth sciences in general and for landscape planning. It defines the reading, interpretation and spatialization of the forms and morphodynamics process, starting from the use of methodologies and specific symbologies attending different taxonomies. Considering this, Technical Manual of Geomorphology (IBGE, 2009) was applied focused on regional cartography with procedures organized into levels, according to Libault (1971), focusing on discussing the process of interpretation, classification and representation, relevant demand to geomorphological mapping, in the case of the Baixada Santista Metropolitan Region in scale 1:100,000. Throughout the interpretation, the contextualization of the evolution of landforms and toponymy stood out as key elements in determining the identity of geomorphological units, as assumed by the technique adopted. It was also clarified that throughout the interpretation there is integration between the classifications and the spatial delimitations of landforms identified in different taxons. From some generalizations and groupings of what was interpreted, imposed by scale and visual acuity on the map, regional geomorphology was represented and characterized, especially geomorphological units and predominant landforms.
\end{abstract}

Keywords: Technical Manual of Geomorphology. Geomorphological Units. Landforms interpretation. Coastal Geomorphology. Geographical research levels.

$\begin{array}{lllll}\text { Caminhos de Geografia } & \text { Uberlândia-MG } & \text { v. 22, n. } 83 & \text { out./2021 } & \text { p. 219-239 Página } 219\end{array}$




\section{INTRODUÇÃO}

Com seus princípios básicos, leis gerais, objetos próprios, métodos e técnicas específicas, a Geomorfologia procura entender a forma e elucidar os processos que operam na superfície terrestre, remetendo à relação entre o estático e o dinâmico, para fornecer uma descrição explicativa em um inventário detalhado das formas de relevo associadas aos processos evolutivos (PENTEADO, 1983).

A cartografia geomorfológica é importante instrumento nesta disciplina por fornecer bases analíticas e sínteses através da indispensável representação da gênese, da idade, das formas de relevo e das relações destas formas com a estrutura e os processos (CASSETI, 2005). Nestes moldes a importância da análise e da cartografia do relevo vão além da própria Geomorfologia e contribuem também com as outras Ciências da Terra e com o planejamento ambiental, neste último caso em temas como fragilidade/vulnerabilidade do ambiente e na legislatura da ocupação (CASSETI, 2005; ROSS, 2012).

Os mapas geomorfológicos apresentam grau de complexidade elevado pela dificuldade de apreender e representar uma realidade relativamente abstrata, incluindo a dinâmica e a gênese das formas de relevo, além da escala (ROSS, 2012). Para o autor outros temas como solos, vegetação, geologia e recursos hídricos têm a representação facilitada pela consolidação de um sistema de taxonomia internacional.

A dificuldade de satisfazer todos os interesses nos estudos geomorfológicos tem guiado o debate sobre a padronização da representação cartográfica, que no Brasil está caminhando para um sistema uniforme em um Sistema Brasileiro de Classificação de Relevo (BOTELHO e PELECH, 2019), com elaboração conduzida pelo Instituto Brasileiro de Geografia e Estatística (IBGE). No caso da cartografia em escala regional, Marques Neto e Ferraro (2018) apontam que a principal contribuição da uniformização das representações e técnicas seria possibilitar correlações regionais proficientes.

Sob influência das formulações clássicas de Penk (1953), base para os esquemas taxonômicos de autores soviéticos Gerasimov e Mescerjacov (1968), além daquelas de autores franceses como A. Cailleux e J. Tricart (1956), todos citados em IBGE (2009), o projeto RADAMBRASIL iniciado em 1971 elaborou os fundamentos de uma cartografia geomorfológica sistemática voltada à representação de todo território nacional em escala regional (BOTELHO e PELECH, 2019). De acordo com estes autores, o acervo e a equipe do Projeto RADAMBRASIL acabaram incorporadas ao IBGE e lançaram as bases do Manual Técnico de Geomorfologia de 1995, que foi revisto em sua estrutura procedimental e foi atualizado para incorporar fundamentos de Sensoriamento Remoto e análises em Sistemas de Informações Geográficas em 2009.

Pelech et al. (2019) designam as técnicas de mapeamento geomorfológico do Projeto RADAMBRASIL, do IBGE e do geógrafo Jurandyr Ross como baseadas em unidades de relevo, nas quais a estrutura hierárquica é funcional às escalas e as formas de relevo são interpretadas conforme as características particulares, como "indivíduos" com nome próprio, diferentemente de outros procedimentos tipológicos que empregam termos genéricos, como os do Serviço Geológico do Brasil (CPRM).

Valendo-se desta lógica de caracterização e de conjuntos de procedimentos de interpretação e representação, o Manual Técnico de Geomorfologia do IBGE (IBGE, 2009) responde ao mapeamento em escala regional pela compartimentação do relevo em um esquema taxonômico entre domínios morfoestruturais, regiões e unidades geomorfológicas e os modelados e formas predominantes de relevo.

Neste sentido, os domínios morfoestruturais correspondem à grandes áreas com certa homogeneidade dada pelos fatores endógenos, pelos litotipos e pelas características estruturais, que interagem com fatores exógenos que destacam regiões geomorfológicas nas estruturas. Estas contêm conjuntos com arranjos altimétricos e fisionômicos semelhantes, as unidades geomorfológicas. A morfogênese nestas unidades é atribuída pelos tipos de modelados dados por processos de dissecação, acumulação, aplainamento e dissolução que elaboram as formas predominantes do relevo (IBGE, 2009).

Embora este manual estabeleça conjuntos de procedimentos, é possível complementar o processo de interpretação caro ao mapeamento com metodologias mais abrangentes como de Libault (1971). Genericamente o autor definiu quatro níveis para pesquisa em Geografia que podem ser aplicados em diferentes segmentos, auxiliando no planejamento, ordenamento e execução organizada dos procedimentos técnicos. Assim, por meio dos níveis compilatório, correlatório, semântico e normativo, a pesquisa pode ser conduzida pelos levantamentos, correlações, interpretações e produções sintéticas, que para Ross (2012) representam o começo, meio e fim ou a "espinha dorsal" do método de trabalho.

Reconhecendo a importância da integração entre procedimentos técnicos e metodológicos numa pesquisa desta natureza, visou-se aplicar os níveis da pesquisa geográfica de Libault (1971) aos procedimentos

$\begin{array}{llllll}\text { Caminhos de Geografia } & \text { Uberlândia-MG } & \text { v. 22, n. 83 } & \text { out./2021 } & \text { p. 219-239 } & \text { Página } 220\end{array}$


técnicos do IBGE (2009) para cartografia geomorfológica, enfocando a discussão das particularidades do processo de interpretação, classificação e representação, além da caracterização do relevo da Região Metropolitana da Baixada Santista, em escala regional (1:100.000).

\section{ÁREA DE ESTUDO}

A Região Metropolitana da Baixada Santista (Figura 1) foi instituída pela lei complementar $\mathrm{n}$ ‥ 815 em 30 de julho de 1996 e abrange área de aproximadamente $2.445 \mathrm{~km}^{2}$, em nove municípios do meso-litoral do estado de São Paulo: Peruíbe, Itanhaém, Mongaguá, Praia Grande, São Vicente, Santos, Cubatão, Guarujá e Bertioga, com cerca de 1,8 milhão de habitantes (GIGLIOTTI e OLIVEIRA, 2015). Na paisagem regional, sob um clima superúmido e subquente parte do Tropical Brasil Central (IBGE, 2002), alternam-se extensos remanescentes florestais nos domínios da Mata Atlântica preservados em fisionomias de Floresta Ombrófila Densa, Restinga e Mangue (SÃO PAULO, 2005) e os usos industriais, portuários e urbanos. Mais de $99 \%$ da população vive nas áreas urbanas que historicamente privilegiaram as planícies principalmente na faixa litorânea em oposição às vertentes íngremes da Serra do Mar e dos morros, ainda que estes últimos estejam parcialmente ocupados na porção insular central, onde se localiza o Porto de Santos, um dos mais importantes do país (GIGLIOTTI e OLIVEIRA, 2015).

Figura 1 - Mapa de localização da Região Metropolitana da Baixada Santista, municípios, áreas urbanizadas e textura topográfica.

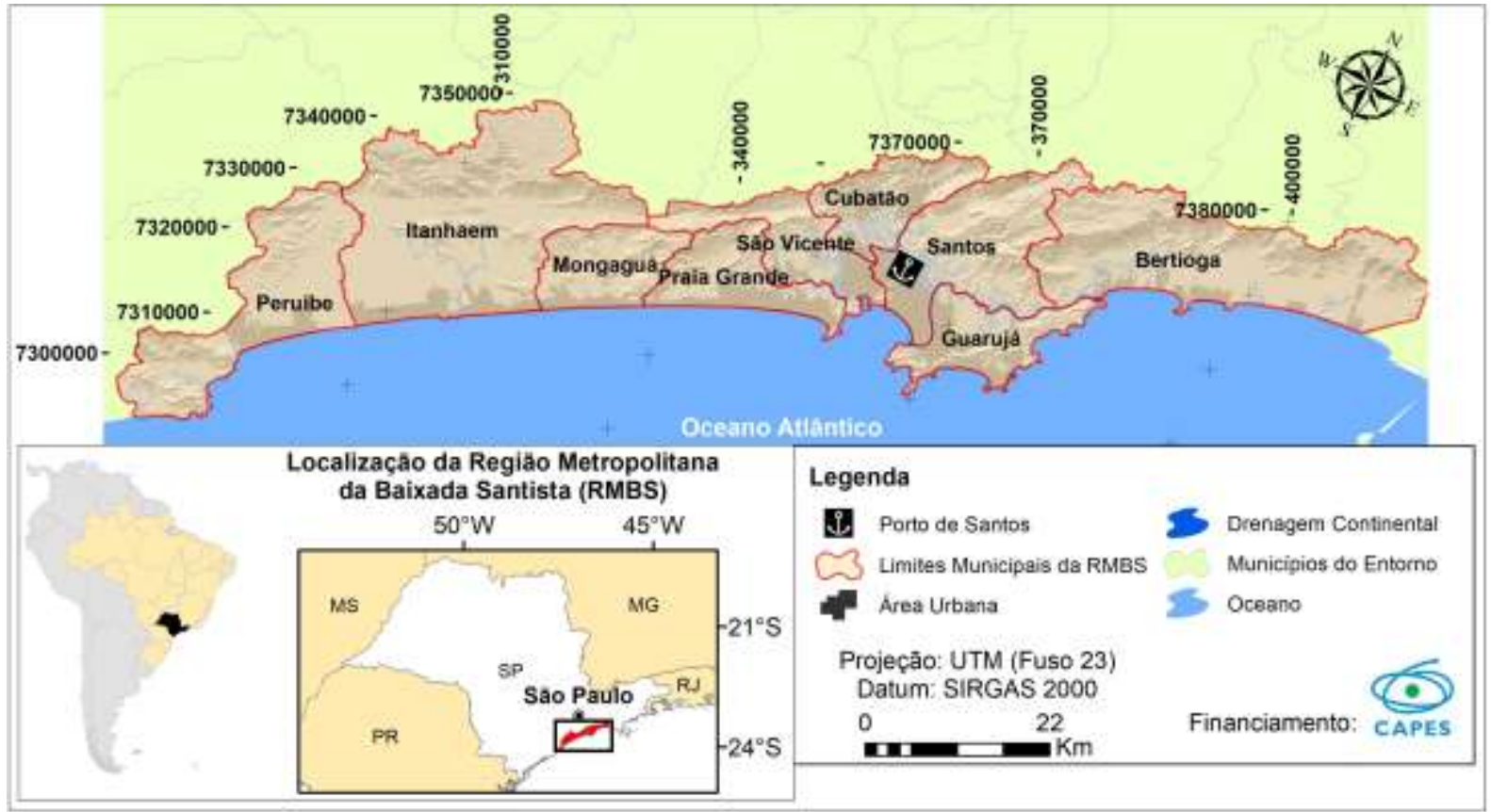

Fonte - IGC e AGEM (2002); IBGE (2015); Projeto MapBiomas (2018). Org.: Autores, 2020.

Compondo cerca de 180 dos mais de 8.000 quilômetros de extensão do litoral brasileiro, a Baixada situase no que Silveira (1964) classificou como litoral sudeste ou das escarpas cristalinas, entre os estados do Rio de Janeiro e de Santa Catarina. Para o autor este trecho é uma grande reentrância marcada pela proximidade do embasamento cristalino na Serra do Mar da linha de costa, formando desníveis abruptos em um litoral recortado.

Em relação ao litoral paulista, cujo alinhamento geral NE-SO é explicado pelo controle exercido pelas maiores estruturas do embasamento pré-cambriano (SOUZA, 2015), a região da Baixada, sobretudo Santos, marca a transição entre um litoral recortado com a Serra mais próxima da costa, com planícies e praias restritas à norte, e outro com recuo das escarpas serranas continente adentro e com planícies e praias mais extensas, contínuas e retilíneas à sul (TESSLER, et al. 2006).

Condicionante das estruturas do relevo, a evolução geológica da costa paulista ocorreu em escalas de tempo distintas e decorreu principalmente dos fenômenos ligados ao soerguimento da Serra do Mar e

$\begin{array}{llllll}\text { Caminhos de Geografia } & \text { Uberlândia-MG } & \text { v. 22, n. 83 } & \text { out./2021 } & \text { p. 219-239 } & \text { Página } 221\end{array}$


subsidência da Bacia de Santos no final do Cretáceo (ALMEIDA, 1976), além dos processos de deposição de sedimentos em eventos glacio-eustáticos ao longo do Quaternário (SUGUIO e MARTIN, 1978).

De maneira geral, de acordo com a CPRM (2006) o embasamento cristalino da Baixada é composto por rochas magmáticas e metamorfizadas em diferentes graus geradas por diferentes fases de dobramentos, metamorfismos e intrusões que remontam majoritariamente ao Neoproterozóico. De acordo com Hasui (2010) estes eventos compuseram o Sistema Orogênico da Mantiqueira no Cinturão de Dobramentos do Ribeira ao longo do Ciclo Brasiliano quando as colisões de pequenos núcleos continentais originaram o supercontinente Gondwana posteriormente fragmentado pelos eventos da reativação sul atlantina mesozoica da qual decorreu intenso fendilhamento da crosta ao longo da abertura do oceano Atlântico.

$\mathrm{Na}$ Baixada Santista estes eventos compressivos e distensivos formaram a estrutura que sustenta o conjunto de ressaltos topográficos que compõe a Serra do Mar e as baías adjacentes sobre as quais geomorfólogos e geólogos divergem quanto à origem e evolução. Neste caso admite-se que estes conjuntos de formas de relevo decorreram de processos tectônicos verticais, concordando com Ab'Saber (1965), Almeida (1976), Almeida e Carneiro (1998), Souza (2015), dentre outros. Neste sentido houve o levantamento da Serra do Mar e a subsidência da Bacia de Santos em movimentos verticais opostos instalados nos sistemas de riftes oriundos da reativação mesozoica, orientado pelos falhamentos transcorrentes pós dobramentos do Cinturão Ribeira (ALMEIDA, 1976).

A Serra do Mar ancestral foi formada durante o cretáceo superior próximo da falha de Santos e foi erodida até a posição atual (ALMEIDA, 1976). Portanto, de acordo com Almeida e Carneiro, (1998) a evolução se deu por erosão regressiva conduzida pela ação de rios, mar e movimentos de massa nas vertentes, que fez a Serra recuar até três a quatro dezenas de quilómetros, abandonando numerosas ilhas e baixios próximos à costa atual.

Para os autores ao longo da evolução da vertente marinha do Planalto Atlântico o relevo recuou subparalelamente à borda da bacia ao longo de sucessivos ciclos erosivos, obedecendo aproximadamente as direções estruturais do embasamento, com influências de estruturas menores, falhas e maciços resistentes à erosão que configuraram diferenças topográficas acentuadas e uma escarpa festonada em muitos trechos. Ab'Saber (1965) aponta que ao longo das fases de clima seco foram conduzidos aplainamentos parciais que reduziram a irregularidade dos blocos abatidos e a energia do relevo tectônico e guiaram o recuo das vertentes assimétricas dos falhamentos iniciais.

Durante o quaternário a epirogenia positiva foi dominante favorecendo o entalhamento fluvial profundo da zona pré-Serra do Mar que ao lado do movimento eustático negativo, representado pela regressão préflanderiana, acentuaram a incisão ou re-incisão e a desarticulação e o insulamento dos baixos esporões antes vinculados à base da Serra do Mar (AB'SABER, 1965). Para o autor os vales decorrentes desta paleohidrografia regional, formados pelo entalhamento em fases úmidas e recuo em fases secas, foram colmatados pelos depósitos marinhos, fluviomarinhos e fluviais, e favoreceram a ingressão das águas e a formação do paleoarquipélago santista-vicentino.

As fases úmidas quaternárias provocaram a erosão fluvial e o entalhamento de vales no conjunto serrano, enquanto as fases secas foram responsáveis por processos de pedimentação restritos e alargamentos dos vales e contribuíram para estreitar e caracterizar os maciços de rochas mais resistentes, que foram insulados nos eventos transgressivos posteriores (AB'SABER, 1965). De acordo com Suguio e Martin (1978) os eventos transgressivos-regressivos das oscilações glacio-eustáticas do Quaternário forneceram a maior parte dos sedimentos para deposição que originou a planície costeira que restou constituída por sedimentos continentais e oceânicos.

Os testemunhos das oscilações indicam uma fase transgressiva mais antiga, a Transgressão Cananéia, datada do pleistoceno que pode chegar até 120.000 anos A.P, e outra fase mais recente, Transgressão Santos, holocênica, com as variações do nível marinho nos últimos 8.000 anos, ambas seguidas por períodos regressivos com intensificação da erosão fluvial (SUGUIO e MARTIN, 1978).

Baseado em Suguio e Martin (1978), Ribeiro (2003) resumiu a evolução e distribuição espacial dos depósitos de origem marinha ao longo destas fases. Para o autor na penúltima grande transgressão (Transgressão Cananéia), o mar entrou em contato com o Embasamento Cristalino em todo o litoral paulista. Areias marinhas litorâneas foram depositadas em grandes paleobaías, que formavam os sítios das atuais planícies sedimentares de Cananéia-Iguape, Itanhaém, Santos, Bertioga e Caraguatatuba, e foram parcialmente destruídos pela drenagem durante a última grande regressão marinha. No último episódio transgressivo (Transgressão Santos) o mar penetrou nas zonas baixas estabelecendo um sistema lagunar, com depósitos arenosos frequentemente iniciados pela construção de ilhas-barreira.

$\begin{array}{lllll}\text { Caminhos de Geografia } & \text { Uberlândia-MG } & \text { v. 22, n. } 83 & \text { out./2021 } & \text { p. 219-239 Página } 222\end{array}$


Ainda conforme o autor, estas ilhas isolaram zonas lagunares, onde houve deposição de sedimentos argilosos ricos em matéria orgânica e durante as fases regressivas houve acréscimo de cordões adicionais, dando origem às extensas planícies de cordões litorâneos.

Destes processos resultou uma paisagem contrastante em termos geomorfológicos, que remete a um passado mais remoto, relacionado aos grandes falhamentos brasileiros, e a outro mais recente, cenozoico e quaternário, relacionado à epirogenia, ciclos erosivos e a eustasia (AB'SABER, 1965).

Este contexto evolutivo acabou por configurar um arranjo geomorfológico complexo de formas que se desenvolveram sobre uma estrutura resistente resultante de processos endogenéticos na Serra do Mar e suas formas residuais abandonadas ao longo do recuo erosivo da escarpa, de um lado, e sobre outra estrutura mais friável derivada de sedimentação formada por processos exogenéticos na planície costeira, de outro lado (GIGLIOTTI e OLIVEIRA, 2015). Concordando com os autores na paisagem atual estes conjuntos de formas se situam no contato direto entre fatores morfodinâmicos continentais e oceânicos altamente complexos, com erosão e sedimentação do continente, resultantes da ação do clima, e processos marinhos litorâneos, como variação da maré, atuação das ondas e correntes.

\section{PROCEDIMENTOS METODOLÓGICOS}

Neste cenário, os quatro níveis de pesquisa de Libault (1971) foram adotados visando cumprir os procedimentos de IBGE (2009), auxiliando pela organização para interpretação e cartografia do relevo numa metodologia particionada em etapas (Figura 2), cuja taxonomia, definições e parâmetros de análise foram empregados conforme o referido manual.

Figura 2 - Níveis, procedimentos e materiais da pesquisa.

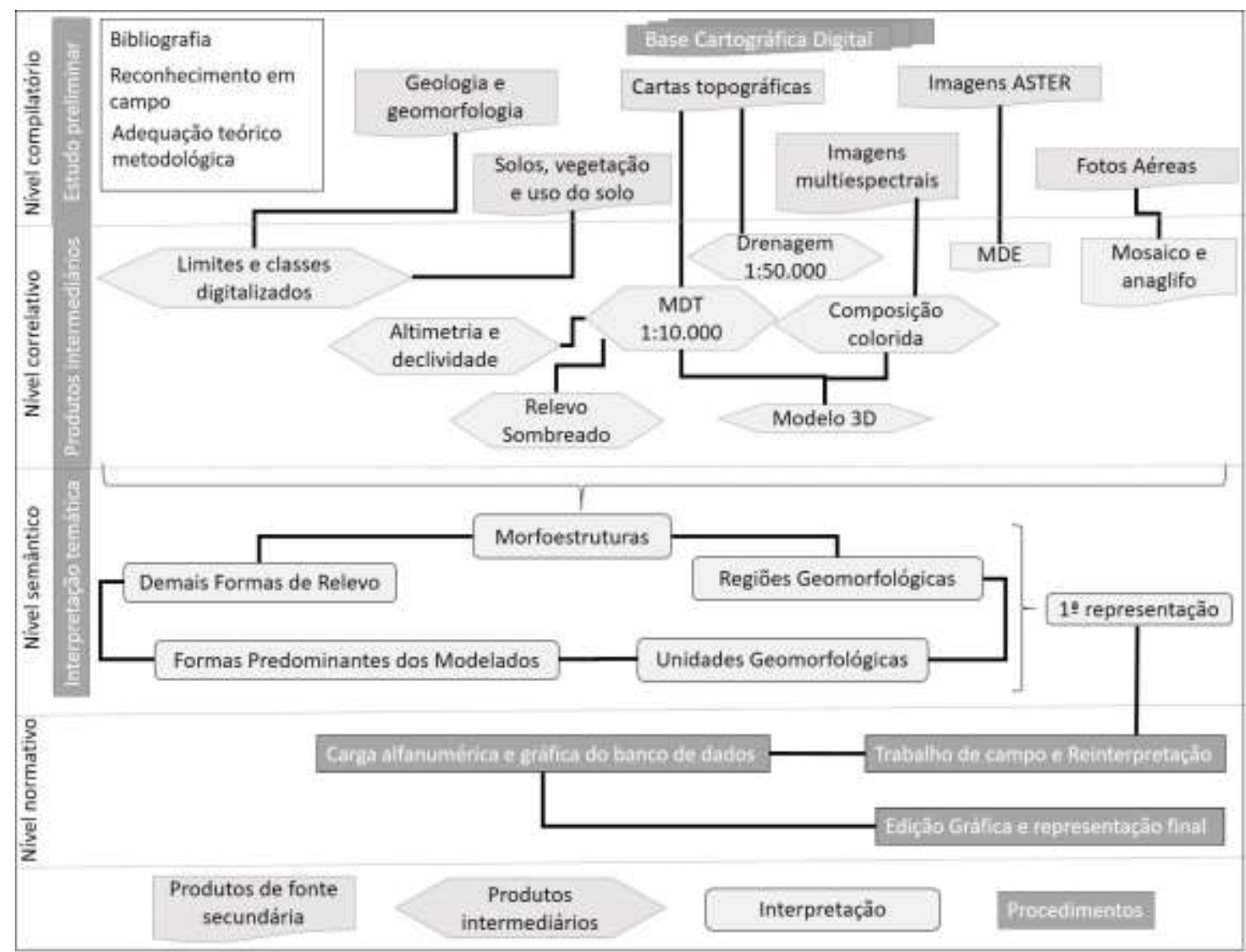

Siglas: MDT - Modelo Digital do Terreno; MDE - Modelo Digital de Elevação; Modelo 3D - Modelo em três dimensões; ASTER - Advanced Spaceborne Thermal Emission and Reflection Radiometer. Fonte - Autores, 2020.
Caminhos de Geografia
Uberlândia-MG
v. 22, n. 83
out./2021
p. 219-239
Página 223 
O primeiro nível, compilatório, foi dedicado aos levantamentos teórico-conceituais e à seleção de informações e materiais significativos para a pesquisa e ocorreu em três frentes básicas: bibliográfica, com relatórios técnicos e textos acadêmicos; de reconhecimento em campo; e de elaboração de base cartográfica digital, pela aquisição, digitalização e adequação de imagens, modelos, cartas e mapas.

No segundo nível, correlativo, os documentos compuseram síntese parcial da pesquisa pelos produtos intermediários, caros às interpretações posteriores. Neste momento foram feitas correlações dos mapas temáticos de geologia, geomorfologia (preexistente), solos, vegetação, uso do solo e drenagem, além da modelagem do relevo (em duas e três dimensões), relação de bandas espectrais de imagens de satélite em composição colorida e mosaico de fotos aéreas.

Já no terceiro nível, semântico, foram interpretados significados geomorfológicos pelos atributos dos produtos intermediários. Caminharam juntos na classificação os significados atribuídos aos indicadores morfométricos e temáticos, as delimitações e as interpretações do relevo.

As etapas anteriores possibilitaram propor uma primeira representação, base para reinterpretação pelos trabalhos de campo. Isto permitiu alcançar o quarto nível, normativo, com a representação dos resultados pela cartografia da geomorfologia regional em escala 1:100.000. Em termos técnicos, para cumprir os procedimentos foi utilizado o programa ArcGIS 16.0® (ESRI, 2018), licenciado para a Universidade Estadual de Campinas. Neste ambiente virtual foi montada a base cartográfica, pelo conjunto de materiais listados no Quadro 1.

Quadro 1 - Base cartográfica com as fontes, escalas ou resoluções especiais e folhas ou articulações.

\begin{tabular}{|c|c|c|}
\hline Material & $\begin{array}{c}\text { Fonte e } \\
\text { escala/resolução } \\
\text { espacial }\end{array}$ & Folha/Articulação \\
\hline $\begin{array}{c}\text { Mapa geológico do Estado de São } \\
\text { Paulo }\end{array}$ & $\begin{array}{l}\text { CPRM (2006); } \\
1: 750.000\end{array}$ & - \\
\hline $\begin{array}{l}\text { Mapa de Unidades Litológicas e } \\
\text { Estratigrafia do Quaternário }\end{array}$ & $\begin{array}{l}\text { Suguio e Martin } \\
(1978) ; 1: 100.000\end{array}$ & Iguape, Itanhaém, Santos e Bertioga \\
\hline Cartas Geomorofológicas & $\begin{array}{l}\text { IBGE (2018); } \\
1: 250.000\end{array}$ & SF23 e SG23 (recorte ao milionésimo) \\
\hline $\begin{array}{c}\text { Mapa Pedológico do Estado de São } \\
\text { Paulo }\end{array}$ & $\begin{array}{l}\text { Rossi (2017); } \\
1: 100.000\end{array}$ & - \\
\hline $\begin{array}{c}\text { Inventário Florestal do Estado de São } \\
\text { Paulo }\end{array}$ & $\begin{array}{l}\text { São Paulo (2005); } \\
1: 25.000\end{array}$ & - \\
\hline $\begin{array}{c}\text { Mapeamento Anual da Cobertura e } \\
\text { Uso do Solo no Brasil }\end{array}$ & $\begin{array}{l}\text { Projeto MapBiomas } \\
(2018) ; 30 \mathrm{~m}\end{array}$ & - \\
\hline Cartas Topográficas & $\begin{array}{l}\text { IBGE }(1984 ; 1973) \\
\text { IGC/SP }(1971 ; 1972) \\
1: 50.000\end{array}$ & $\begin{array}{c}\text { Salesópolis, Mogi das Cruzes, Santos, Riacho } \\
\text { Grande, Embu-Guaçu, Pedro de Toledo, Rio } \\
\text { São Lourencinho, Bertioga, Mongaguá e } \\
\text { Itanhaém }\end{array}$ \\
\hline Cartas Topográficas & $\begin{array}{c}\text { IGC e AGEM (2002); } \\
1: 10.000\end{array}$ & 128 folhas do SCM-BS (entre 1022 e 6346) \\
\hline Imagens Sentinel-2B & $\begin{array}{l}\text { ESA e USGS (2018); } \\
10 \mathrm{~m}\end{array}$ & T22KHU, T23KMP e T23KLP \\
\hline $\begin{array}{c}\text { Modelo Digital de Elevação Global } \\
\text { (GDEM) ASTER }\end{array}$ & $\begin{array}{l}\text { METI e NASA (2011); } \\
\text { 30m }\end{array}$ & $\begin{array}{c}\text { S24W046, S24W047, S24W048, S25W047 e } \\
\text { S25W048 }\end{array}$ \\
\hline $\begin{array}{l}\text { Ortofotocartas Região Metropolitana } \\
\text { da Baixada Santista }\end{array}$ & $\begin{array}{l}\text { IGC e AGEM (2002); } \\
1: 10.000\end{array}$ & 128 folhas do SCM-BS (entre 1022 e 6346) \\
\hline \multicolumn{3}{|c|}{ Fonte - Autores, 2020.} \\
\hline
\end{tabular}


A cartografia geomorfológica do IBGE (2018) representou fio condutor para recompartimentação do relevo. As nomenclaturas foram mantidas para o caso das morfoestruturas e regiões geomorfológicas e foram revistas e ampliadas para as unidades de relevo de acordo com as interpretações propostas.

Quanto à geologia os aspectos utilizados foram a litologia, em seus tipos e idades, e as estruturas. Foi necessário compilar duas representações conforme a adequação do detalhamento da informação, com o mapa da CPRM (2006) utilizado para os afloramentos do embasamento cristalino na Serra do Mar e relevos residuais e o de Suguio e Martin (1978) para a planície costeira.

A vegetação em suas fitofisionomias Floresta Ombrófila Densa, Restinga e Mangue, de acordo São Paulo (2005), e os solos em classes (ordem), identificados por Rossi (2017), forneceram indicadores para os tipos e limites das unidades e formas de relevo, uma vez que se distribuem associadas entre si e às condições geológicas-geomorfológicas. Os usos do solo foram utilizados neste momento para estabelecer os limites espaciais da atuação antropogênica sobretudo na modificação da cobertura vegetal e na remobilização dos solos.

Por sua vez, os canais de drenagem foram obtidos das cartas topográficas IBGE $(1984 ; 1973)$ e IGC/SP (1971; 1972) e utilizados para análise da hierarquia pelo método de Strahler (1956 apud CHRISTOFOLETTI, 1981) com uso do ArcGIS 10.6® (ESRI, 2018) (padronização dos dados pelas ferramentas topology, merge e explode) e QGIS 2.18 (programa livre) (hierarquização com o plug in "Strahler"), isto além dos padrões de drenagem, conforme IBGE (2009), aferidos visualmente.

Adiante, a modelagem do relevo, das imagens multiespectrais e ortofotocartas foi imprescindível. Importante ressaltar que um Modelo Digital de Elevação (MDE) foi considerado uma representação contínua do relevo, incluindo também a cobertura do solo, enquanto um Modelo Digital do Terreno (MDT) uma representação matemática pela interpolação de dados altimétricos (LIPORACl et al., 2003).

O MDE utilizado trata-se de um mosaico de imagens ASTER GDEM (METI e NASA, 2011). Por sua vez, os dois MDT's foram obtidos pela interpolação com uso da ferramenta Topo to Raster. Um foi interpolado pelos atributos pontuais (pontos cotados) e lineares (cotas altimétricas) de cartas 1:50.000, resultando num modelo com $30 \mathrm{~m}$ de resolução espacial. O outro, pelas cartas 1:10.000 resultou num modelo de $10 \mathrm{~m}$ de resolução espacial.

A aferição da representatividade dos três modelos foi feita considerando as informações de campo e a observação da altimetria, elaborada pela ferramenta slice. Então, a partir do modelo selecionado foram processados a declividade pela ferramenta slope e o relevo sombreado pela hillshade, empregados respectivamente na análise de rupturas topográficas e dos conjuntos de formas de relevo.

Por sua vez, as imagens multiespectrais foram reunidas em um mosaico e recortadas conforme a área de interesse. Tais imagens foram feitas no dia 22/05/2018 pelo sensor MSI do satélite Copernicus Sentinel$2 \mathrm{~B}$, órbita 138, nos canais azul, verde, vermelho, e no infravermelho próximo (NIR). Foi feito o empilhamento destes canais e foi gerada uma composição colorida falsa cor no sistema RGB, respectivamente, com imagens do infravermelho próximo, vermelho e verde.

A partir do MDT e da composição colorida, ambos com 10 metros de resolução espacial, foi criado o modelo tridimensional do relevo, no programa ArcScene $10.6 \AA$, também com resolução espacial de 10 metros. Neste mesmo programa pelo comando Stereo View nas configurações de visualização (View Settings) foi gerado anaglifo do mosaico de ortofotocartas, particularmente útil na identificação das transições dos depósitos de encosta e de algumas variações nas formas de relevo da planície costeira.

\section{RESULTADOS E DISCUSSÕES}

\section{A metodologia de unidades de relevo aplicada à Baixada Santista}

As interpretações da geomorfologia regional foram conduzidas conforme as características morfológicas e evolutivas das morfoestruturas, definidas pelo IBGE (2018) como Cinturões Móveis Neoproterozóicos e Depósitos Sedimentares Quaternários. Nestes dois grandes conjuntos, o primeiro de caráter endogenético e o segundo exogenético, configuram-se compartimentos de planaltos, serras, escarpas, morros e morranias, de um lado, e extensos baixos distribuídos entre depósitos alúvio-coluvionares, terraços e planícies, de outro.

Subdividindo tais estruturas o IBGE (2018) reconheceu quatro regiões geomorfológicas na Baixada Santista adotadas neste caso: Escarpas e Reversos da Serra do Mar do Paulista e Planalto de Paranapiacaba, sustentados pelas estruturas cristalinas e com morfogênese pela disseção; e as Formas

$\begin{array}{lllll}\text { Caminhos de Geografia } & \text { Uberlândia-MG } & \text { v. 22, n. } 83 & \text { out./2021 } & \text { p. 219-239 Página } 225\end{array}$


Agradacionais Atuais e Subatuais Interioranas e as Planícies Deltaicas, Estuarinas e Praiais, com acumulação de sedimentos continentais e/ou marinhos.

Conforme as observações a partir da base cartográfica, as Escarpas e Reversos da Serra do Mar Paulista correspondem ao padrão típico da Serra do Mar da porção central e norte do litoral do estado, com escarpas abruptas próximas da linha de costa e alinhamento NE-SO controlado majoritariamente pelas falhas de Cubatão e Bertioga. Já o Planalto de Paranapiacaba representa padrões mais típicos da Serra do Mar do litoral sul paulista, com alinhamento no mesmo sentido mas com recuo das escarpas continente adentro, sendo a Serra de Itatins uma exceção a este padrão geral. Por outro lado as Formas Agradacionais Atuais e Subatuais Interioranas são compostas por sedimentos continentais fluviais ou originados de erosão das encostas das serras e morros enquanto as Planícies Deltaicas, Estuarinas e Praiais foram formados pela atuação direta de processos marinhos litorâneos e incluem sedimentos arenosos, lagunares de baía, de mangues e pântanos.

Ainda que brevemente proposta, a contextualização da gênese e evolução do relevo regional mostrou-se fundamental quando se passou ao nível taxonômico seguinte, das unidades geomorfológicas. Neste momento cabe ressaltar que a metodologia de unidade de relevo do IBGE (2009), como apontado por Pelech et al. (2019), baseia-se em sintagmas toponímicos ao propor unidades, associando termos gerais sobre os tipos de compartimentos aos termos específicos que singularizam a identidade do elemento. Esta foi a composição adotada para unidades geomorfológicas identificadas.

Aplicada à Baixada Santista, as características gerais das unidades foram designadas conforme os compartimentos: planalto, escarpa, serra, morro, morrania, depósito, planície e terraço. Estes foram associados aos termos que dão identidade evolutiva, como formas residuais, festonamentos, alinhamentos, deposição continental ou litorânea, além da toponímia.

É possível exemplificar com uma das unidades interpretadas: os "Morros Residuais da Serra do Mar". Nestes, o compartimento "morro" é o termo geral acompanhado pelo processo evolutivo "residual", remetente ao recuo erosivo da serra e separação das formas, e pela toponímia "Serra do Mar". Adiante, nas unidades geomorfológicas foi possível identificar os padrões de formas de relevo dos modelados.

\section{O nível semântico e a interpretação integrada da geomorfologia}

Ainda que os limites e as denominações das morfoestruturas e das regiões geomorfológicas tenham sido adotadas do IBGE (2018), houve um necessário refinamento dos limites destas macroformas ao longo das classificações feitas em níveis taxonômicos de maior detalhe.

Neste sentido, a adoção de Labault (1971) permitiu alocar procedimentos necessários para interpretações em diferentes escalas taxonômicas num mesmo nível na pesquisa, o semântico. Portanto o raciocínio de interpretação empregado não foi estritamente taxonômico e hierarquizado, no qual aparentemente encerra-se a interpretação de um conjunto de escala de menor detalhe quando se passa ao seguinte de maior detalhe, mas transcorreu integrado.

Além da delimitação das unidades geomorfológicas partindo das morfoestruturas e regiões geomorfológicas e, após, retroalimentando-as com limites mais precisos, outro exemplo foi a classificação da planície costeira. Nesta, a distinção e os limites das unidades geomorfológicas de gênese continental e litorânea só foram esclarecidos quando se passou a um detalhe maior, na análise das formas de relevo.

Entretanto, cabe ressaltar que conforme ocorreu o avanço na escala e no detalhamento alterou-se a importância atribuída aos materiais utilizados. Os trabalhos de Suguio e Martin (1978), da CPRM (2006) e do IBGE (2018) estiveram em primeiro plano para interpretação das morfoestruturas, mas quando intencionou-se a regionalização, a proposta do IBGE (2018) assumiu protagonismo.

Por sua vez, para as unidades geomorfológicas foram necessárias técnicas variadas, inicialmente baseadas em modelos do relevo. Deste ponto em diante, na classificação das formas predominantes os materiais e técnicas diferiram conforme demandado pelos modelados de dissecação ou acumulação.

Nos modelados de dissecação prevaleceu a importância dos modelos do relevo. Para os modelados de acumulação a modelagem do relevo, as imagens multiespectrais e as fotografias aéreas forneceram indicadores e limites das formas que demandaram complementação pelos trabalhos sobre unidades quaternárias. Estes, por sua vez, forneceram a composição material e idade relativa dos depósitos.

Os MDT's e o MDE, seus produtos derivados, os canais de drenagem e o modelo tridimensional forneceram parâmetros fundamentais para classificação das unidades geomorfológicas e representaram

$\begin{array}{llllll}\text { Caminhos de Geografia } & \text { Uberlândia-MG } & \text { v. 22, n. } 83 & \text { out./2021 } & \text { p. 219-239 } & \text { Página } 226\end{array}$


ponto de partida na identificação das formas de relevo. Entretanto, além das possibilidades também sobressaíram os limites destes materiais, principalmente na interpretação da planície costeira.

Num primeiro momento, da análise do MDT das cartas 1:50.000 emergiu a demanda por melhor detalhamento nas variações altimétricas nas áreas de baixada, causada pelos poucos pontos amostrais disponíveis para interpolação. Para as mesmas áreas a análise do MDE evidenciou a necessidade de dirimir as distorções ocasionadas pela cobertura do solo, principalmente pelo dossel das árvores e, sobretudo, pela urbanização verticalizada próximo a linha de costa. Entretanto, os dois modelos não distorceram significativamente as formas associadas aos modelados de dissecação.

A demanda por detalhamento foi solucionada pela interpolação de cartas 1:10.000 em um MDT cuja qualidade foi comparada aos outros dois modelos pela hipsometria (Figura 3), destacando trechos em Itanhaém e Peruíbe, na linha 1, da llha de São Vicente, na linha 2, e de Bertioga, na linha 3.

Figura 3 - Hipsometria da Região Metropolitana da Baixada Santista: variações aferidas em diferentes setores da planície litorânea (1: Peruíbe-Itanhaém; 2: Ilha de São Vicente e entorno; e 3: Bertioga) por diferentes modelos do relevo (A: MDT 1:10.000; B: MDT 1:50.000; C: MDE Topodata), 2020.

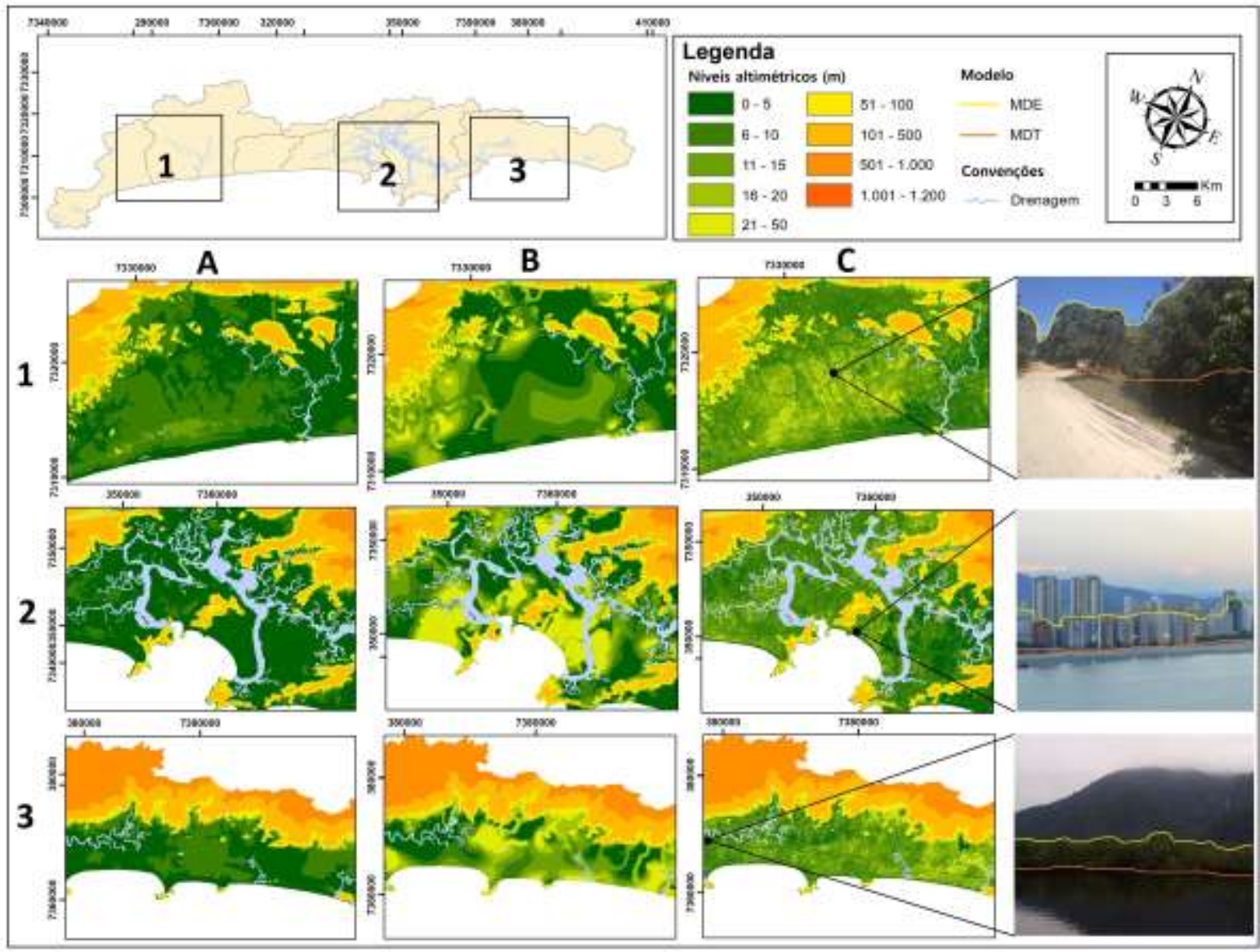

Fonte - IBGE (1984; 1973); IGC (1971; 1972); IGC e AGEM (2002); METI e NASA (2011). Org.: Autores, 2020.

Além de possibilitar boa caracterização das formas dos modelados de dissecação pelo relevo sombreado, hipsometria e clinometria, o MDT pelas cartas 1:10.000 permitiu também distinguir os níveis altimétricos na planície costeira, assumidos como um dos indicadores na classificação de planícies ou terraços.

Outro recurso importante utilizado para interpretação visual foi o modelo tridimensional, proposto a partir da sobreposição de imagens multiespectrais ao MDT mais adequado. Privilegiou-se imagens de média a alta resolução com composição incluindo o canal do infravermelho próximo, como recomendado por IBGE (2009), pela sensibilidade à umidade, destaque da rede de drenagem, da intensidade de dissecação, da morfologia e do contato entre diferentes unidades geomorfológicas.
Caminhos de Geografia
Uberlândia-MG
v. 22, n. 83
out./2021
p. $219-239$
Página 227 
O modelo tridimensional (Figura 4) foi instrumento útil para interpretação visual permitindo identificar com clareza as unidades geomorfológicas e as formas predominantes dos modelados de dissecação. A partir dele foi interpretado o tipo predominante de dissecação, as formas dos topos e o grau de entalhamento, associado a densidade de canais, conforme observado na drenagem.

Figura 4 - Modelo em três dimensões da Região Metropolitana da Baixada Santista: feições geomorfológicas interpretadas com as setas amarelas indicando o sentido da observação em 1, 2, 3 e 4.

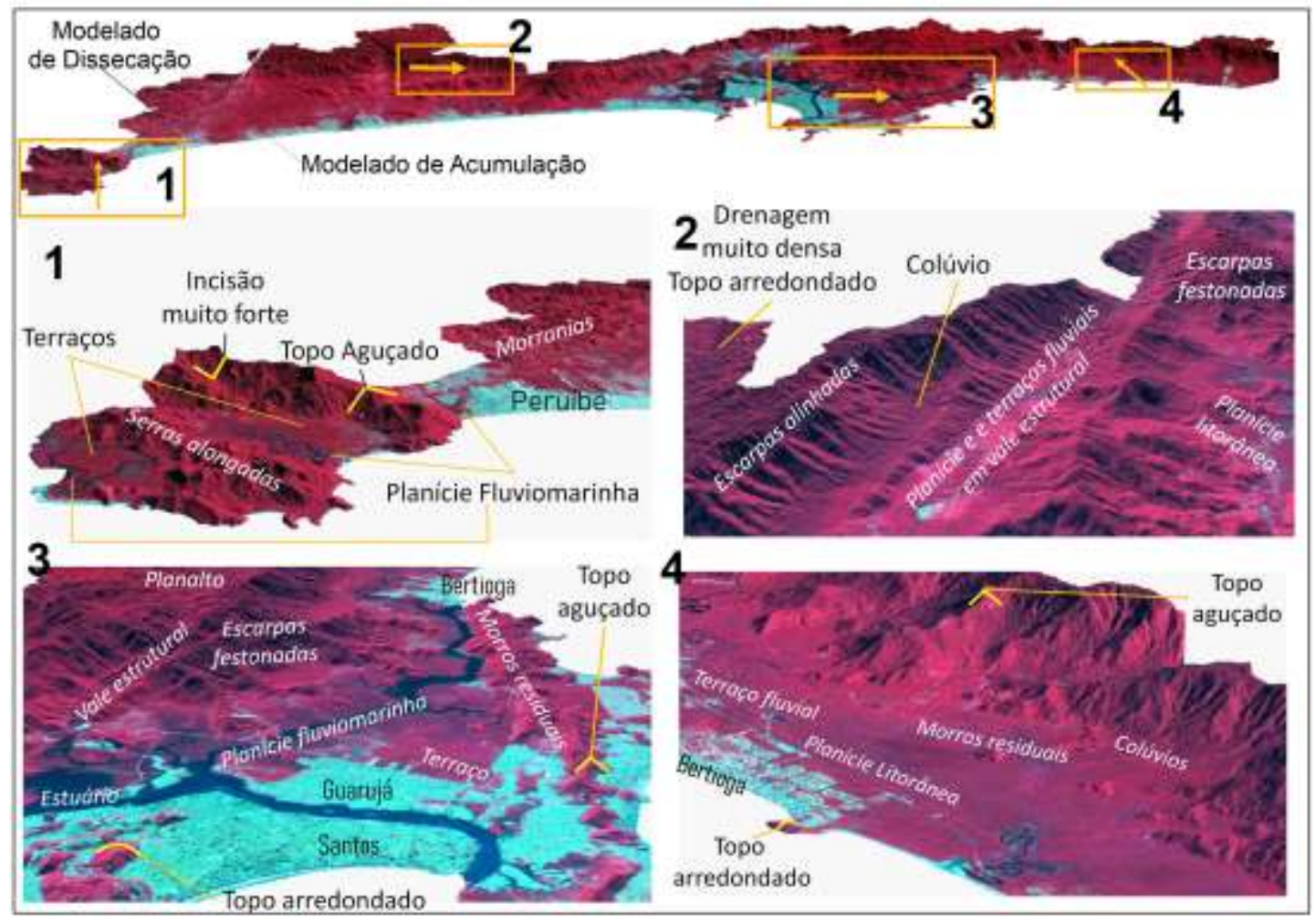

Fonte - IGC e AGEM (2002); ESA e USGS (2018). Org.: Autores, 2020.

No entanto, os modelos do relevo não tiveram mesma efetividade para as classificações nos modelados de acumulação. Embora o modelo tridimensional tenha contribuído para o reconhecimento de inúmeras rampas coluvionares, limites inequívocos das planícies fluviomarinhas e indicadores de terraços como paleocanais, meandros abandonados e cristas de praia.

Ainda dentro de um processo de interpretação integrado, as unidades geomorfológicas nas áreas de acumulação foram esclarecidas somente quando se passou à interpretação das formas predominantes de relevo. Neste sentido, o trabalho de Suguio e Martin (1978) que retratou sistematicamente as unidades quaternárias de toda região foi o material elementar, atualizado ou complementado quando cabível, como no caso da planície de Itanhaém pelo proposto por Giannini (1987), de Cubatão por Ribeiro (2003) e de Bertioga por Souza (2015).

Estes trabalhos possibilitaram a reconstituição genética e a caracterização da composição material e foram complementados pelas formas de relevo interpretadas nas imagens multiespectrais, pelos indicadores topográficos, da pedologia e da vegetação e pela interpretação do mosaico e anaglifo das fotografias aéreas além dos trabalhos de campo.

Especificamente, as unidades quaternárias de Giannini (1987) em escala 1:50.000 foram úteis para detalhar os limites das deposições com material de origem continental nos sopés das escarpas, serras, morros e morranias em Peruíbe, Itanhaém e Mongaguá. Também auxiliaram especificar os depósitos marginais aos rios Itanhaém e Peruíbe como fluviolagunares, menos genéricos que a classe fluviomarinholagunares, proposta em Suguio e Martin (1978). Porém este não foi o único procedimento para classificação em depósitos fluviolagunares. Na planície de Bertioga, em cartografia 1:35.000 de

$\begin{array}{lllll}\text { Caminhos de Geografia } & \text { Uberlândia-MG } & \text { v. 22, n. } 83 & \text { out./2021 } & \text { p. 219-239 }\end{array}$


Souza (2015), isto se deu pela junção e generalização de depósitos fluviais e lagunares de menores dimensões.

Justamente este trabalho foi o que representou maior impacto em termos de reclassificações e redelimitações das unidades quaternárias. A partir da generalização das classes mapeadas por Souza (2015) foi proposta nova distribuição espacial e temporal para os depósitos da planície em Bertioga.

A partir da classificação dos depósitos pelas unidades quaternárias seguiu-se uma revisão utilizando o mapeamento pedológico de Rossi (2017). Considerando solos como indicadores, os de horizonte espódico estiveram associados aos depósitos arenosos e os de horizontes sálicos às áreas de influência de maré. O mapeamento de cobertura vegetal proposto por São Paulo (2005) serviu a mesma função e auxiliou pelas fitofisionomias dos mangues, indicando as planícies fluviomarinhas, e dos limites entre a floresta e as restingas, indicando as transições entre os depósitos continentais e litorâneos.

Após, as fotografias aéreas em escala 1:10.000 (IGC; AGEM, 2002) em anaglifos foram fundamentais nas delimitações finais, principalmente das rampas coluvionares e dos terraços. As classificações foram verificadas em campo, registrados em fotografias ilustradas na Figura 5. Nesta destacam-se a planície fluviomarinha do entorno do canal Mar Pequeno em São Vicente (Figura 5.1a), a escarpa retilínea da Serra do Mar em Cubatão (Figura 5.1b), a ruptura topográfica entre terraços marinhos pleistocênicos (Figura 5.2a) e holocêncios (Figura 5.2b) em São Vicente e a transição entre rampa coluvionar (Figura 5.3a) e os depósitos alúvio-coluvionares de baixada em Peruíbe (Figura 5.3b).

Figura 5 - Baixada Santista: Fotos de campo. 5.1a: planície fluviomarinha no canal estuarino "Mar Pequeno" em São Vicente; 5.1b: escarpas retilíneas da Serra do Mar em Cubatão (7349,330N; 356,088S); 5.2a: terraço marinho pleistocênico alçado topograficamente; 5.2b: terraço marinho holocênico em São Vicente $(7351,029 \mathrm{~N} ; 358,994 \mathrm{~S}) ;$ 5.3: transição entre rampa coluvionar (a) e depósitos aluvio-coluvionares de baixada (b) em morranias em Peruíbe (7316,587N; 297,287S). Data: 07/2019.

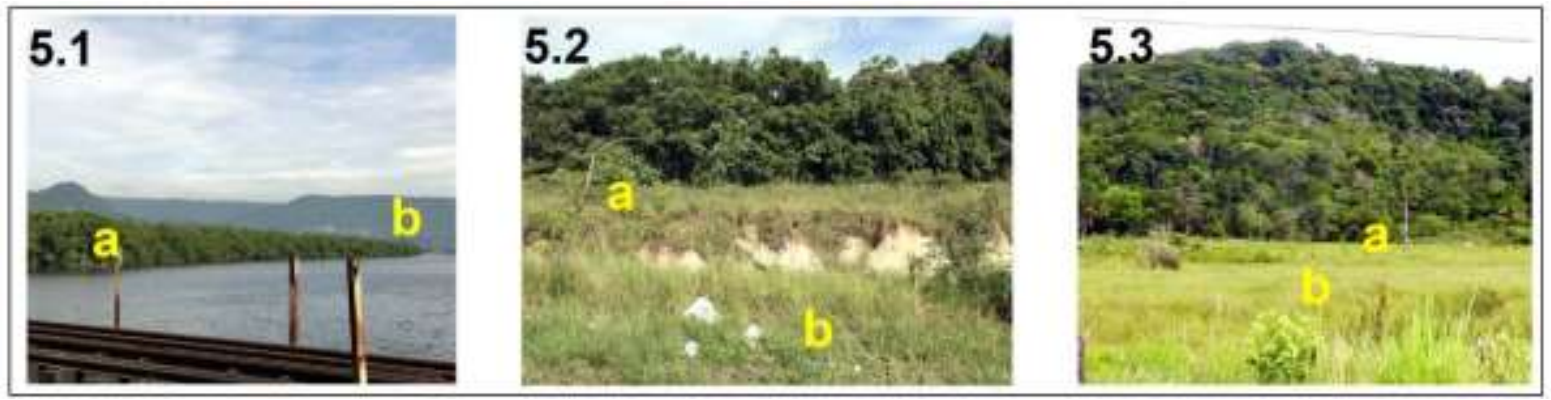

Fonte - Autores, 2020

Por todo exposto, os resultados obtidos com interpretações dos canais de drenagem, de imagens multiespectrais e dos referidos modelos, complementados pelos trabalhos de campo, foram suficientes para a classificação das formas predominantes de relevo dos modelados de dissecação. Já os modelados de acumulação exigiram maior detalhamento pela complexidade para interpretação e classificação e, nestes casos, os trabalhos sobre unidades quaternárias foram essenciais, associados às fotointerpretações e aos trabalhos de campo.

Estas diferenças quanto aos procedimentos decorreram da alta complexidade geomorfológica da área de estudo. Posicionar estes conjuntos de procedimentos, variados conforme a taxonomia e os modelados, num mesmo nível da pesquisa foi importante para interpretação integrada e classificação do relevo.

\section{Geomorfologia da Baixada Santista: representação e caracterização}

Compondo nível normativo, na cartografia foram representados os aspectos do relevo condicionados pela escala 1:100.000. Neste caso a legenda foi proposta pelo emprego de polígonos coloridos associados a descritores sobrepostos por símbolos pontuais e lineares. Isto permitiu representar ordenadamente em uma tabela a gênese, a dinâmica e as formas do relevo, as quais acrescentou-se a cronologia relativa.

Associada aos modelados de dissecação a legenda representou a gênese pela dissecação homogênea (D) e estrutural (DE), acrescidas da letra minúscula indicativa da forma do topo: (c) topos convexos ou (a) aguçados. Tais informações foram complementadas pela dissecação do relevo, indicadora da forma e

$\begin{array}{lllll}\text { Caminhos de Geografia } & \text { Uberlândia-MG } & \text { v. 22, n. } 83 & \text { out./2021 } & \text { p. 219-239 Página } 229\end{array}$


dinâmica, com o primeiro dígito referente ao plano horizontal, pela densidade de drenagem entre 1 e 5, e o segundo ao plano vertical, com a incisão da drenagem nos mesmos dígitos (IBGE, 2009).

Quanto aos modelados com gênese pela acumulação, a legenda primeiramente incluiu a letra (A). Adiante houve diferenciação entre as formas em planícies $(p)$, terraços $(t)$ e planícies e terraços (pt), as quais foram adicionadas informações sobre a dinâmica e a origem do material entre fluviais (f), marinhos $(\mathrm{m})$ e lagunares (lg), agrupados ou não conforme condicionado pela escala. Neste momento foi necessário incluir a classe fluviomarinholagunares (fmlg) não prevista no manual adotado. Também foram representados os depósitos gravitacionais, de enxurrada e de inundação de origem alúvio-coluvionar, tipificados como rampas de colúvio (rc) e plano inundável indiferenciado (ii) (IBGE, 2009).

Além destas características representadas em polígonos e descritores, também foram adotadas simbologias para linhas e pontos, demais constituintes do alfabeto cartográfico, voltados para algumas formas particulares, como para os tipos de escarpa ou para os pontões. Apesar destes procedimentos, não foi possível representar tudo que foi interpretado por conta da acuidade visual relacionada à escala. Então a generalização ocorreu em graus variados conforme o compartimento.

As formas dos modelados de dissecação mais generalizadas foram os morros residuais tanto da Serra do Mar quanto do Planalto de Paranapiacaba, nos quais foram representados o tipo de dissecação e a forma de topo, com a indicação das variações nos índices de dissecação. Nos modelados de acumulação a generalização da representação se deu na junção de formas de planícies e terraços e/ou pela distinção do material dos depósitos em classes genéricas, como no caso dos terraços fluviomarinholagunares (fmlg).

Os padrões de forma melhor representados ocorreram em áreas mais homogêneas. As mais fidedignas nos modelados de dissecação foram os planaltos, com as variações do tipo de dissecação, formas do topo e índices de dissecação mais próximos do que foi interpretado. Certa homogeneidade também coube à representação das áreas escarpadas nas quais um padrão de dissecação estrutural, com topos aguçados, vertentes abruptas, densidade de drenagem mediana e incisão muito forte sobressaiu tanto nas formas alinhadas quanto festonadas. Nos modelados de acumulação a homogeneidade na forma e constituição material foi melhor representada na planície e nos terraços marinhos.

Ao todo foram cartografadas 11 unidades geomorfológicas, a partir da compartimentação e da identidade das formas. Pela compartimentação as unidades variaram entre planalto, escarpa, serra, morro, morrania, depósito, planície e terraço. Pela identidade, em termos de evolução as unidades variaram entre formas residuais, festonamentos, alinhamentos, sedimentação continental ou litorânea, além da toponímia. Nestes moldes a cartografia da geomorfologia da Baixada Santista está ilustrada na Figura 6, folha Itanhaém (1/3), Figura 7, folha Santos (2/3), Figura 8, folha Bertioga (3/3), seguidos pela Legenda na Figura 9. A necessidade da subdivisão nesta comunicação decorreu da extensão alongada da área.

Figura 6 - Mapa Geomorfológico da Região Metropolitana da Baixada Santista, Folha Itanhaém (1/3).

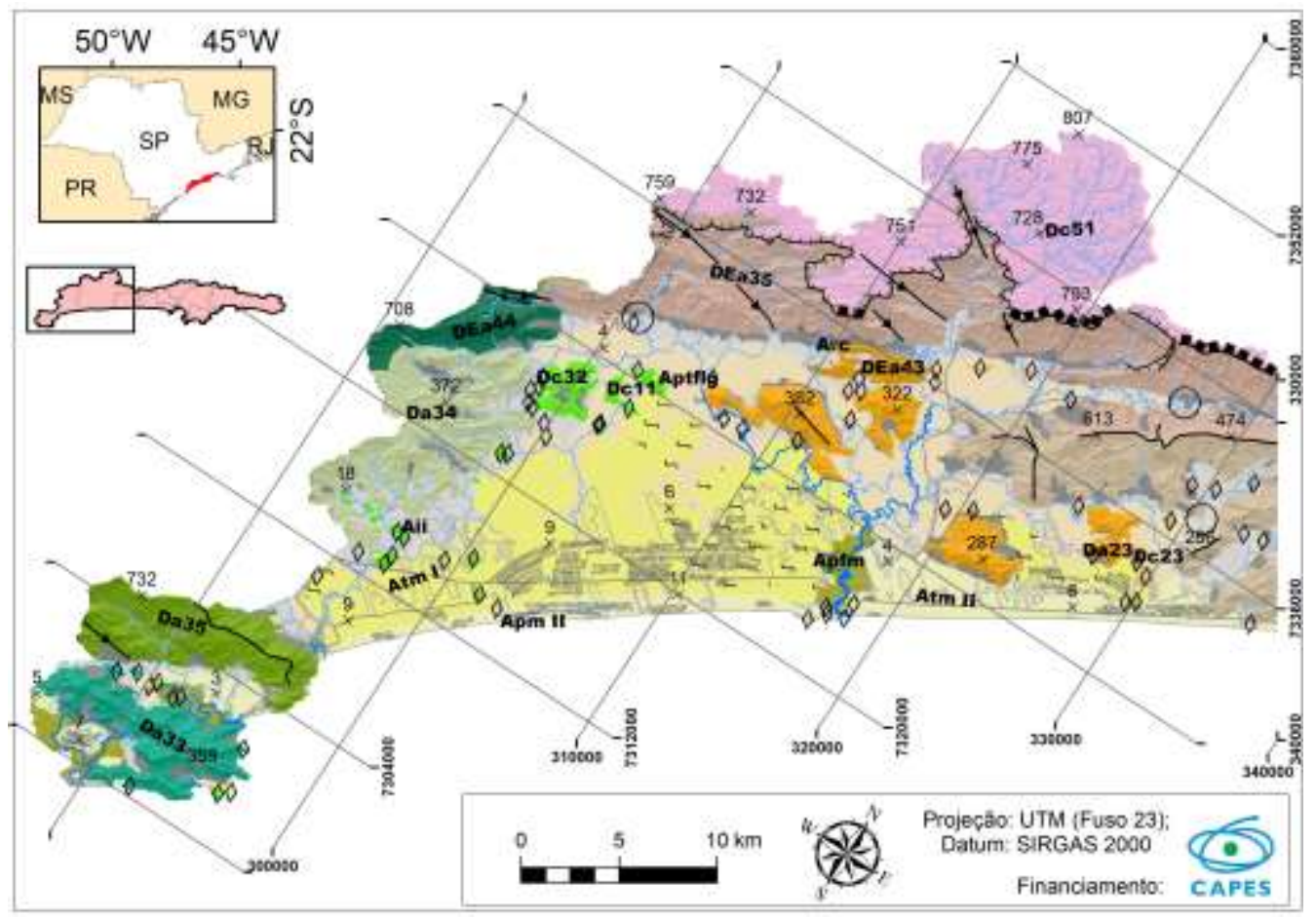

Fonte - Autores, 2020. 
Figura 7 - Mapa Geomorfológico da Região Metropolitana da Baixada Santista, Folha Santos (2/3).

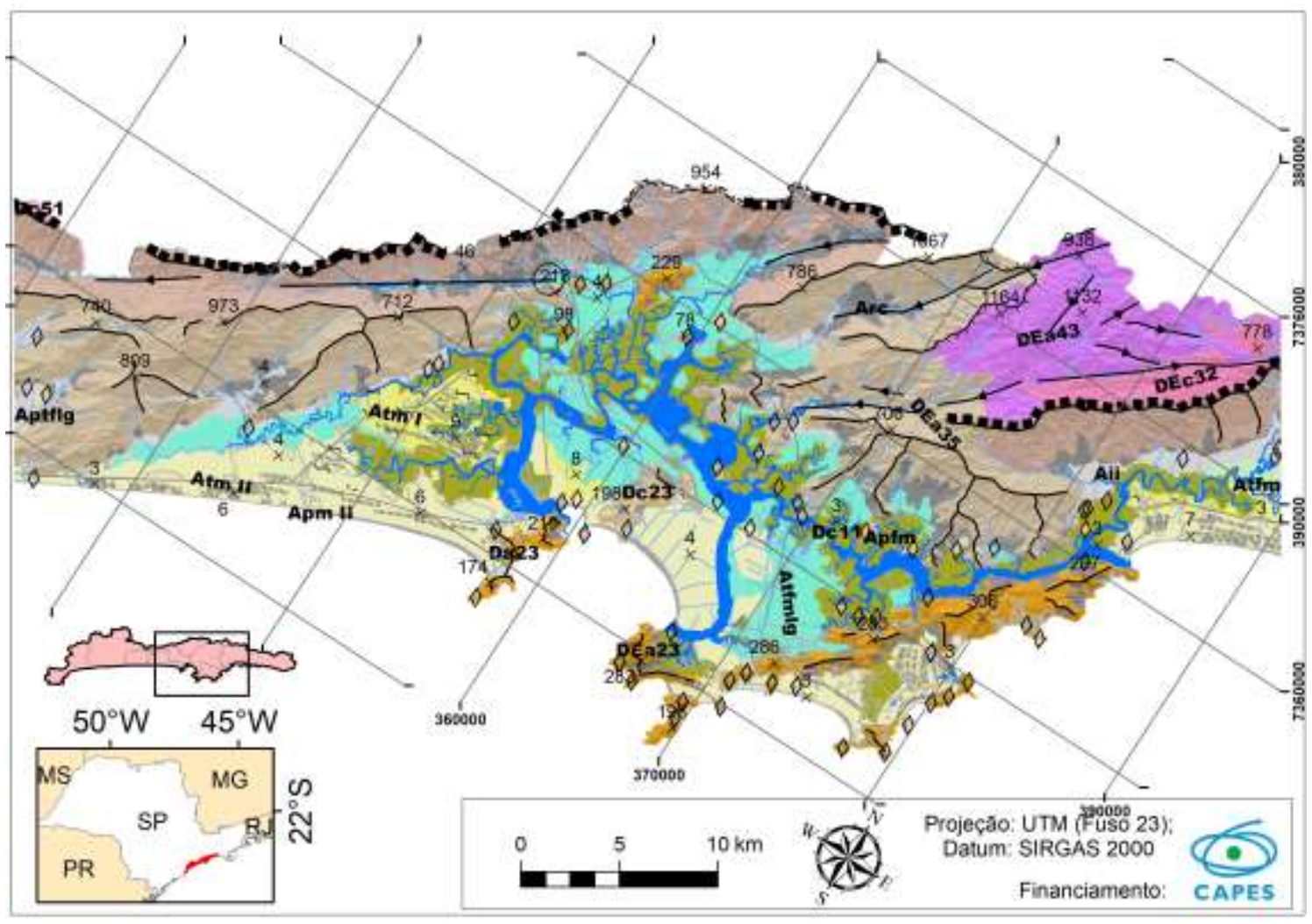

Fonte - Autores, 2020.

Figura 8 - Mapa Geomorfológico da Região Metropolitana da Baixada Santista, Folha Bertioga (3/3).

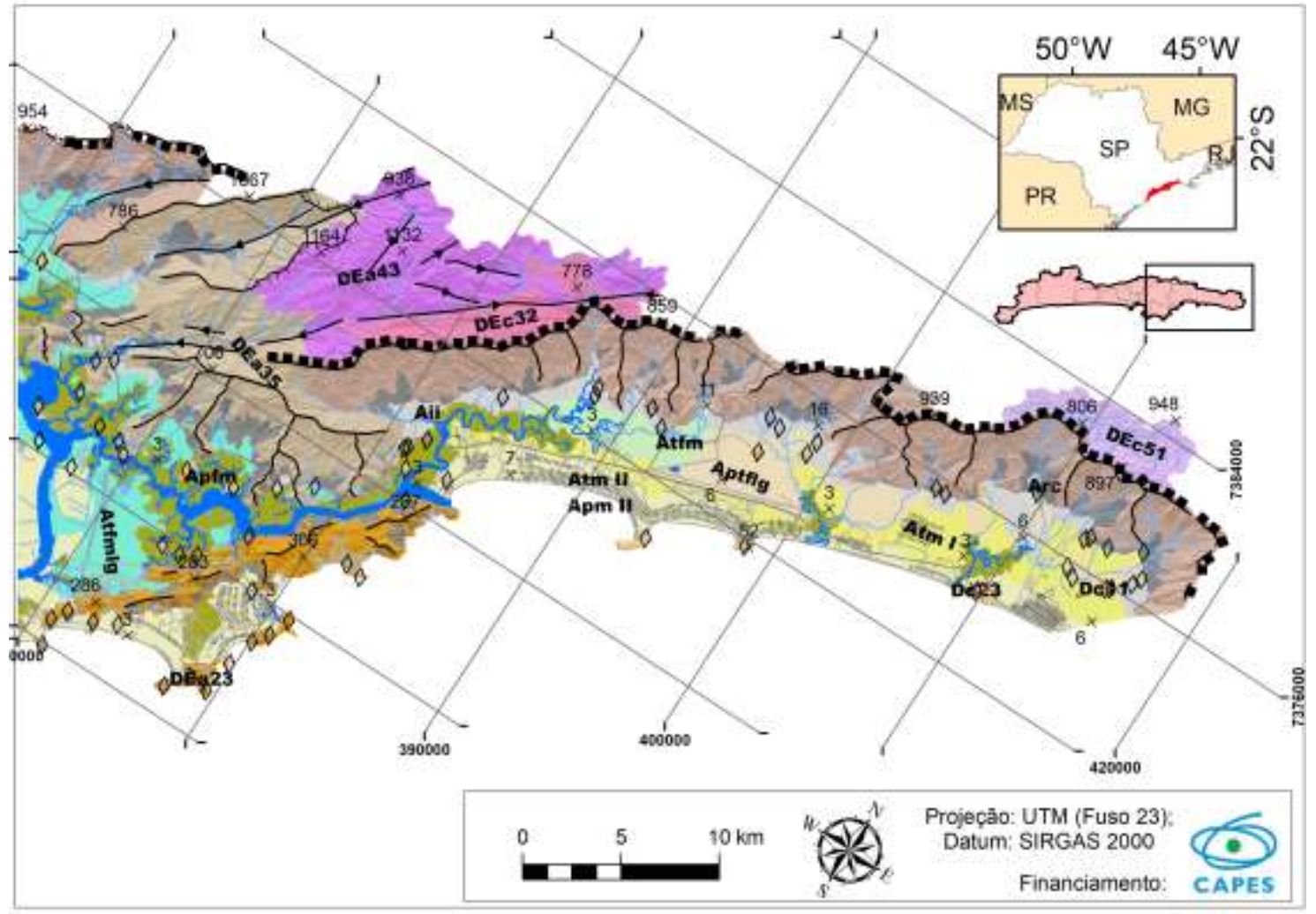

Fonte - Autores, 2020.

p. $219-239$

Página 231 
Figura 9 - Legenda do Mapa Geomorfológico da Região Metropolitana da Baixada Santista.

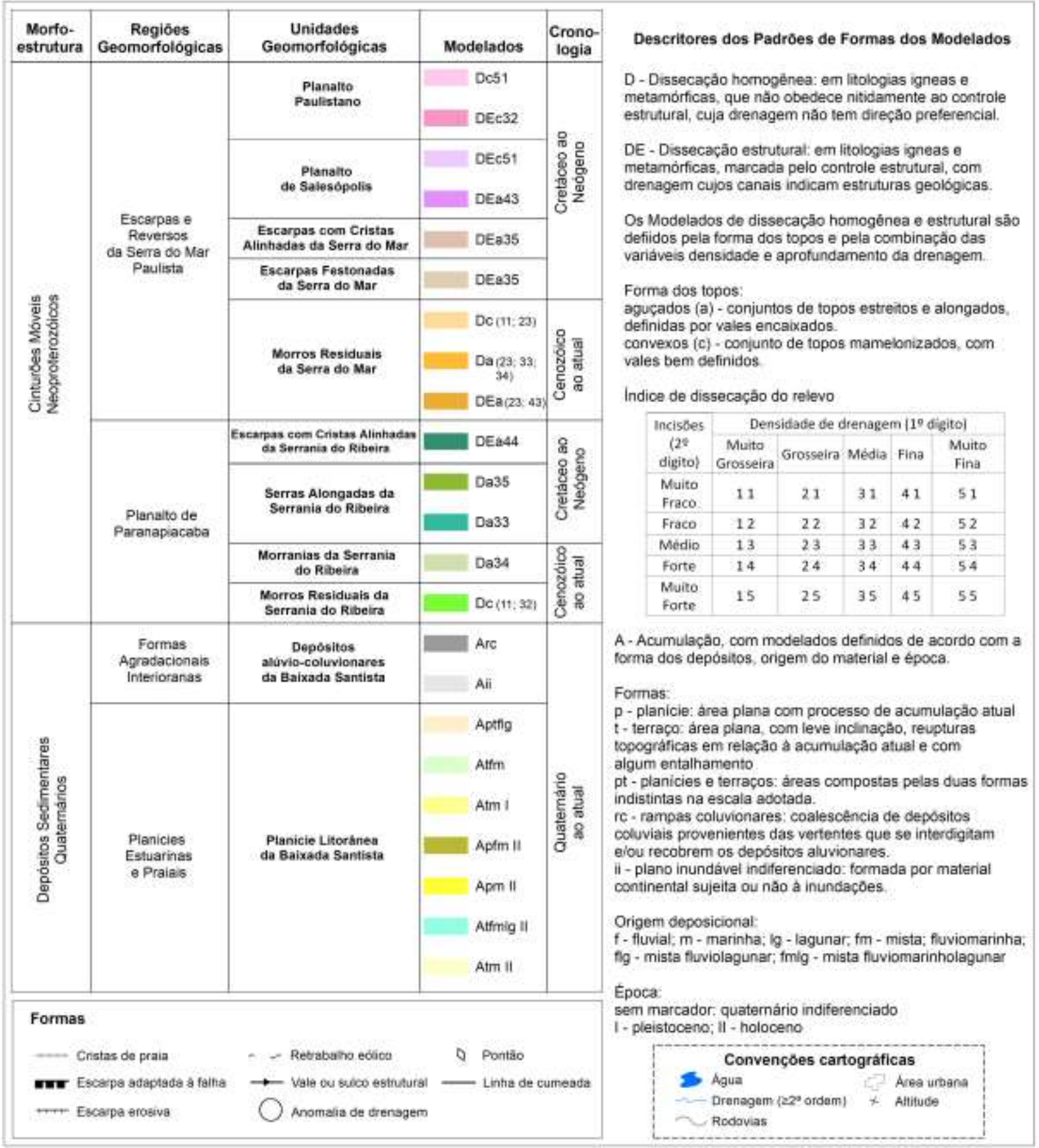

Fonte - Autores, 2020.

O IBGE (2018) classificou quatro unidades geomorfológicas modeladas pela dissecação na Baixada Santista: Serra do Mar Paulista, Planalto Paulistano, Serrania do Ribeira, Planalto de Salesópolis; e duas unidades modeladas pela acumulação: Planícies alúvio-coluvionares e Planícies Litorâneas.

Restaram mantidos os planaltos Paulistano e de Salesópolis, unidades que mantiveram seus atributos apesar do detalhamento. Caso semelhante ocorreu nas áreas de acumulação nas quais foram mantidas as unidades, que foram acrescidas com detalhe das formas e dinâmica quando se passou as formas predominantes de relevo dos modelados. Já a Serrania do Ribeira foi subdividida entre escarpas festonadas, serras alongadas, morranias e morros residuais. Mesmo procedimento foi proposto para a Serra do Mar Paulista na qual foram distinguidas escarpas com cristas alinhadas, festonadas e morros residuais.
Caminhos de Geografia
Uberlândia-MG
v. 22, n. 83
out./2021
p. 219-239
Página 232 
A rede hidrográfica regional atua dissecando todos os compartimentos de relevo do Cinturão Orogênico Neoproterozóico onde há predomínio de canais de $1^{\mathrm{a}}$ e $2^{\mathrm{a}}$ ordem. Nos planaltos a drenagem ocorre com densidade mais elevada enquanto nas escarpas, serras e morranias se caracteriza pelo aprofundamento das incisões. Por outro lado a intensa sedimentação fluvial do material oriundo dos processos erosivos das encostas serranas, a pequena declividade e a consequente diminuição da energia do relevo e da velocidade das águas são responsáveis pelo processo de deposição e pelas características dos rios na planície costeira, que majoritariamente desaguam no mar em canais de $4^{\underline{a}}$ ordem ou superior.

As formas mais elevadas e interioranas da região são os planaltos Paulistano e de Salesópolis, com altitudes entre 551 e 1249 metros, que compõe os reversos das escarpas da Serra do Mar. Na Baixada, o Planalto Paulistano é composto principalmente por relevo colinoso com densidade de canais muito alta e média com incisão fraca e muito fraca e topos convexos esculpido em ortognaisses e xistos. A altitude média é de 739 metros, com amplitude altimétrica de 465 metros (entre 551 e 1016 metros), declividade média de $18,2^{\circ}$, que predomina entre 8 a 20ํㅡㄴ com drenagem em padrão dendrítico onde há dissecação homogênea (D) e, conforme o controle estrutural (DE), treliça.

O Planalto de Salesópolis difere do anterior pelas altitudes mais elevadas (de 674 a 1179), com média de 898 metros e maior amplitude (505 metros) e, conforme IBGE (2018), pelo predomínio de topos aguçados e pelo controle estrutural (DE) mais marcante, no qual prevalece o padrão de drenagem em treliça. Esta unidade, na Baixada, foi esculpida sobre rochas de complexos ortognáissicos e de granito Taiaçupeba, sob os quais se desenvolveram basicamente colinas e morros, cristas alinhadas nos relevos montanhosos orientadas preferencialmente na direção ENE-OSO, com densidade de drenagem alta e muito alta e incisões médias e muito fracas.

Se nos planaltos a altitude se destaca, nas áreas escarpadas esta dá lugar à declividade. Avançando das áreas mais altas, frequentemente próximas dos 1000 metros, para as mais baixas, próximas ao nível do mar, há um desnível abrupto escarpado, dissecado conforme orientação estrutural (DE), com topos angulosos, densidade de drenagem média e incisão muito forte. Este desnível foi subdividido conforme toponímia em escarpas da Serrania do Ribeira e da Serra do Mar Paulista e de acordo com a evolução e a forma em cristas alinhadas e festonadas. Acrescenta-se a este conjunto de formas abrutas a Serra de Itatins (Serra Alongadas), pontão com dissecação predominantemente homogênea (D) que pelo contato direto com o mar divide o Litoral Sul paulista e a Baixada Santista.

Os maiores desníveis altimétricos ocorrem nas escarpas da Serra do Mar Paulista, com seu máximo nos trechos com cristas alinhadas em que chega a 1229 metros (entre 1249 e aproximadamente 20 metros) e nos festonados a 1160 metros (entre 1180 e aproximadamente 20 metros). O desnível mantém-se alto nas Serras Alongadas de até 1028 metros (entre 1028 e 0 metros), enquanto na escarpa da Serrania do Ribeira diminui e encontra os menores valores, alcançando 670 metros (entre 676 e 6 metros). A declividade acompanha a amplitude altimétrica com altos valores nestas unidades, com predomínio no intervalo entre 20 a 30ำ, frequentemente acima dos $45^{\circ}$ no terço superior das vertentes.

De modo geral, a Serra do Mar Paulista perpassa toda a Baixada Santista com direcionamento geral NESO, representando um paredão de escarpa adaptada a falha que se estende desde Peruíbe, onde dista $15 \mathrm{~km}$ do litoral, até Ubatuba (SP), onde está em contato direto com o oceano. As escarpas apresentam trechos com topos alinhado (Cristas Alinhadas), com orientação paralela a linha de costa condicionada pelos conjuntos de falhas regionais, e festonados (Festonadas), com esporões, cristas e vales estruturais perpendiculares ao direcionamento da escarpa, com intensa erosão remontante (IBGE, 2018).

Mais especificamente, as Escarpas com Cristas Alinhadas apresentam grandes espigões subparalelos assim como o padrão de drenagem, vertentes com perfis retilíneos orientadas para sul e sudeste e vales fechados controlados por grandes sistemas de falhas, principalmente a de Cubatão (GIGLIOTTI, 2010). Por vezes a erosão remontante delineia escapas erosivas que se alternam com as de falha, diferenciando trechos de recuo relativamente paralelo de outros sob influência da incisão da drenagem.

As Escarpas Festonadas, outra unidade da Serra do Mar Paulista, se relacionam com o encaixe da drenagem em linhas de falhas que conduziram a erosão e o recuo com a preservação dos topos (GIGLIOTTI, 2010). Isto formou um modelado de festões com predominância de vertentes côncavas e convexas escalonadas em patamares, orientadas de maneira mais complexa para sudeste, sul, leste e sudoeste, com linhas de cumeada dispersas. As escarpas, alternam declives abruptos e patamares, com anfiteatros sucessivos separados por espigões e drenagem no padrão dendrítico encaixada nas falhas.

Já a Serrania do Ribeira, parte das escarpas da Serra do Mar na região do Planalto de Paranapiacaba, é composta por relevo bastante movimentado, com altitude menores e com forte controle estrutural e

$\begin{array}{llllll}\text { Caminhos de Geografia } & \text { Uberlândia-MG } & \text { v. 22, n. 83 } & \text { out./2021 } & \text { p. 219-239 } & \text { Página } 233\end{array}$


litológico (IBGE, 2018). Isto se manifesta, dentre outras, em formas de relevo com alinhamentos de cristas e linhas de cumeada com vertentes íngremes, vales profundos ou sulcos estruturais e drenagem com padrão subparalelo encaixada com a presença de corredeiras, caso das Escarpas com Cristas Alinhadas da Serrania do Ribeira.

Destacando-se como um grande pontão que avança até o mar com orientação E-O, condicionada pela Zona de Cisalhamento de Itariri de acordo com CPRM (2006), as Serras Alongadas interrompem a continuidade da planície costeira e fogem ao padrão de orientação geral das escarpadas (NE-SO). Com relevo predominantemente serrano em forma de espigão com topos aguçados e vertentes em séries de patamares que escalonam os valores de declividade, com drenagem em padrão dendrítico, densidade de drenagem média e incisão muito forte, representam marco na divisão entre o Litoral Sul e central (Baixada) do estado de São Paulo.

As demais unidades dos modelados de dissecação decorrem de longínquo processo de desgaste erosivo ao longo de todo Cenozóico e recuo das escarpas continente adentro com abandono de formas de relevo residuais que se intercalam com a planície costeira como afloramentos do embasamento cristalino, ou ainda, em conjuntos que ainda não foram totalmente destacados da Serra do Mar, como no caso das morranias, asseverado em Gigliotti (2010).

As Morranias da Serrania do Ribeira representam morros com topos aguçados interconectados não destacados completamente dos compartimentos serranos, como uma extensão intensamente rebaixada do Planalto de Paranapiacaba. A amplitude altimétrica é de 408 metros (entre 413 e aproximadamente 5 metros de altitude), mas em média de 117 metros, que representa menos da metade da média de altitude das escarpas adjacentes. A drenagem tem padrão geral dendrítico, com densidade média e incisões fortes, resultando numa declividade média de $18,3^{\circ}$ que acompanham as demais formas de relevo residuais, predominando na classe de 8 a $20^{\circ}$.

Adentrando a planície costeira, diferentemente das morranias há inúmeros trechos da Serra do Mar separados do conjunto principal classificados como Morros Residuais da Serrania do Ribeira e Morros Residuais da Serra do Mar Paulista, remetendo ao conjunto do qual possivelmente foram destacados conforme indicado pela distância e alinhamento das formas.

Os Morros Residuais da Serra do Mar Paulista em geral são alinhados aos padrões gerais da Serra, como uma continuidade interrompida pela planície costeira. Há desde morros extensos com dissecação marcadamente estrutural e topos aguçados (DEa), como no caso do maciço principal da llha de Santo Amaro, município de Guarujá, até pequenos outeiros em pontões. Já os Morros Residuais da Serrania do Ribeira apresentam-se mais rebaixadas geralmente em "meia laranja" e outeiros com topos convexos e menores valores de dissecação.

Em termos morfométricos a primeira unidade apresenta maiores valores, com amplitude altimétrica de 444 metros, altitude média de 87 metros e declividade média de 20ㅡㄴ, enquanto a segunda apresenta 172 metros de amplitude, altitude média de 38 metros e declividade média de 15,5․

Os morros residuais são formas que possuem estreita relação com a planície costeira. Constituíram-se como pontos de amarração à sedimentação como pode ser observado nos alinhamentos das sucessivas cristas de praia ou cordões regressivos. Também configuraram-se como ponto de apoio à instalação da foz de cursos d'água de grande porte (para os padrões regionais) no rio Itanhaém, nos canais estuarinos da llha de São Vicente e de Santo Amaro e nos rios Itaguaré e Guaratuba no município de Bertioga.

Nos domínios da planície costeira as unidades e os modelados dos Depósitos Sedimentares Quaternários manifestam a face oposta da alta intensidade de intemperismo e erosão, comportando-se como áreas receptoras e acumuladoras destes materiais de granulometria muito variada, seja nos sopés das encostas, ao longo dos rios ou mesmo nas desembocaduras fluviais e dos estuários.

Ao fundo da planície, no contato com as escarpas, serras, morros e morranias, distribuídos de maneira relativamente plana, em rampas ou ao longo de pequenas planícies, encontram-se os depósitos de processos erosivos, gravitacionais e fluviais de origem continental, os Depósitos Alúvio-Coluvionares.

Como descrito por IBGE (2018) tais depósitos são superfícies de terras baixas planas ou em rampas, com presença de leques de espraiamento e cones de dejeção em alguns pontos. Souza (2015) descreve-os como depósitos de encosta embutidos nos anfiteatros do sopé da Serra do Mar que ora se interdigitam com os depósitos da planície, ora os recobrem. A estes acrescentam-se as pequenas planícies fluviais dos vales encaixados nos sopés das escarpas.

$\begin{array}{lllll}\text { Caminhos de Geografia } & \text { Uberlândia-MG } & \text { v. 22, n. } 83 & \text { out./2021 } & \text { p. 219-239 Página } 234\end{array}$


Os depósitos em rampa (Arc) compreendem as formas embutidas nos anfiteatros do sopé da Serra em altitudes que por vezes ultrapassam os 400 metros sob forma de alvéolos coluvionares ou rampas no sopé dos morros e fundos de vale. Com inclinações suave a média, foram descritos em Souza (2015) como compostos por detritos de coalescência das vertentes, com sedimentos com ampla variação granulométrica, desde argilas até matacões.

Por outro lado, os depósitos que recobrem as porções mais planas da planície costeira junto às encostas da Serra do Mar formam Planos Inundáveis Indiferenciados (Aii), com associação não individualizada de planícies fluviais e colúvios de baixada. De acordo com Suguio e Martin (1978) ambas são compostas por areias e argilas.

Já as formas de relevo de origem marinha e mista que compõe a unidade geomorfológica da planície marinha formam um ambiente mais complexo com praias, tombolos e barras atuais e, principalmente, por formas herdadas da sucessão e justaposição de cordões litorâneos regressivos e terraços marinhos de diferentes épocas, por vezes redistribuídos pelo vento, associados também à deposição fluviomarinha: fluviais, lagunares, paludiais (pântanos) e de planície de maré (SUGUIO e MARTIN, 1978; GIANNINI, 1987; SOUZA, 2015).

Ao longo do Holoceno houve contínua progradação conforme indica a disposição dos cordões litorâneos, que devido ao paralelismo, indicam regimes de ondas com características muito semelhantes às atuais durante ao menos todo o período posterior ao máximo transgressivo holocênico (TESSLER et al. 2006). Para os autores, apesar do histórico progressivo da linha de costa, corroborado pela ausência de marcadores de mudanças bruscas no clima de ondas incidentes na área, as praias, formas predominantes da estreita planície marinha (Apm), comportam-se de maneiras diferenciadas, mas tendem a ser dissipativas a intermediárias.

Depositados ao longo das oscilações glacio-eustáticas da transgressão-regressão Cananéia e da transgressão-regressão Santos, o material arenoso sustenta atualmente, respectivamente, os modelados de terraços marinhos pleistocênicos (Atm I), mais alçados (entre 3 a $20 \mathrm{~m}$ com altitude média de 5,6 m), e os terraços marinhos holocênicos (Atm II) (entre 1 a $7 \mathrm{~m}$ com altitude média de 3,8 m), ambos com sucessivas gerações de cristas de praias, retrabalhados ou redistribuídos pelo vento em alguns trechos. Estes terraços têm seus limites principalmente em rupturas topográficas e atuam como divisores de água e barramentos para os rios da planície.

Acompanhando o padrão geral de distribuição dos depósitos marinhos do estado, os terraços sustentados por depósitos pleistocênicos (Atm I) são mais resistentes e alçados topograficamente. Distribuem-se sobretudo na planície de Itanhaém, em trechos dos municípios de Peruíbe, Itanhaém e Mongaguá (SUGUIO e MARTIN, 1978; GIANNINI, 1987). Na porção central da Baixada concentram-se na área continental do município de São Vicente, conforme Suguio e Martin (1978), mas na planície de Bertioga alongam-se paralelos à linha de costa como em antigas ilhas-barreira, de acordo com Souza (2015).

Por sinal, a distribuição alongada paralela a linha de costa representa um padrão geral de distribuição dos terraços holocênicos (Atm II) na região, que adentram nas planícies de Santos em maiores extensões e preenchem toda a planície do Guaraú, conforme observado em Suguio e Martin (1978).

Estas formas em terraços marinhos acabaram por configurar barreiras que ao longo do Quaternário permitiram o desenvolvimento de paleolagunas e paleobaías, nas quais se desenvolveram depósitos mistos em termos estratigráficos. Nestes foi possível registrar as variações pelas formas do relevo em planícies e terraços ou apenas como terraços sobre estratigrafias mistas. Com altitude entre $1 \mathrm{a} 15 \mathrm{~m} \mathrm{e}$ altitude média de $4,05 \mathrm{~m}$ as planícies e terraços fluviolagunares apresentam maior amplitude que os terraços fluviomarinholagunares (entre 3 a $8 \mathrm{~m}$ com $3,41 \mathrm{~m}$ de altitude média) e os terraços fluviomarinhos (entre 3 a $12 \mathrm{~m}$, com altitude média de 4,09 m).

As planícies e terraços fluviolagunares, alocados principalmente nas planícies de Itanhaém e Bertioga, são depósitos em ambientes paleolagunares formados ao longo das incursões holocênicas ou mesmo em período anterior, com material enriquecido com matéria orgânica, conforme detalhado em Giannini (1987) e Souza (2015). Nestes houve intensa deposição de areais e argilas aos quais se somaram deposições fluviais que atualmente se distribuem em formas de planícies, que acompanham os rios e tributários, e terraços, que apresentam pequenas variações topográficas, antigos leitos, barras e meandros abandonados, que se concentram sobretudo em Itanhaém.

$\begin{array}{lllll}\text { Caminhos de Geografia } & \text { Uberlândia-MG } & \text { v. 22, n. } 83 & \text { out./2021 } & \text { p. 219-239 Página } 235\end{array}$


Por sua vez, nos terraços fluviomarinholagunares foi distinguida somente a forma, ligeiramente alçada em termos altimétricos sobremaneira em relação à planície fluviomarinha atual. Estes terraços, também foram formados em ambientes de paleobaías e paleolagunas com deposição de areias e argilas com estreita influência de processos fluviais, de acordo com Suguio e Martin (1978).

Já os terraços fluviomarinhos foram classificados desta forma relacionando a complexidade do ambiente deposicional do baixo curso do rio Itapanhaú. Neste caso, de acordo com Souza (2015), são terraços fluviais antigos e alçados entre 7 e $10 \mathrm{~m}$ acima do nível do mar atual com depósitos de planície de inundação, leitos e barras, entremeados por depósitos reliquiares de ambientes fluviais e marinhos pleistocênicos a holocênicos.

Por fim, na porção mais baixa da planície costeira (entre 0 a $4 \mathrm{~m}$ com altitude média de 2,8 $\mathrm{m}$ ) formada pela atuação de fatores marinhos litorâneos e continentais, as planícies fluviomarinhas (Apfm) representam as áreas onde há atuação da maré associada à fluvial. Nestas, os sedimentos argilosos de mangue e pântano, de acordo com Suguio e Martin (1978), são ricos em matéria orgânica e estão em processo de colmatagem nas desembocaduras fluviais e estuários de água salobra.

\section{CONSIDERAÇÕES FINAIS}

Pelos procedimentos adotados foi possível cartografar a geomorfologia da Região Metropolitana da Baixada Santista em escala 1:100.000, distribuída em três folhas e codificada em uma legenda que possibilita leitura taxonomicamente organizada dos tipos, da gênese e da idade das forma de relevo, requisitos básicos para cartografia geomorfológica.

Nem todas as formas de relevo interpretadas puderam ser representadas, o que ilustra interpretação e representação configurarem diferentes níveis da pesquisa. A interpretação demanda e recorre a um olhar mais detalhado para o reconhecimento das formas de relevo enquanto a representação demanda e impõe generalização ou agrupamento do que foi interpretado. Neste caso, como pressupõe as metodologias de unidades de relevo, a contextualização da evolução e a toponímia foram essenciais para especificação da identidade dos compartimentos e da morfocronologia ao longo da classificação do que foi interpretado.

No decurso do trabalho, a adoção de níveis de pesquisa possibilitou discutir separadamente as particularidades do processo de interpretação e classificação e de representação, com esclarecimentos que podem auxiliar na condução de propostas semelhantes. Colaborando com os procedimentos, o raciocínio em níveis ajudou na interpretação admitindo articulação permanente dos diferentes táxons no decorrer de todo processo de classificação e delimitação espacial. No entanto cada táxon condicionou importância variada aos procedimentos e materiais utilizados.

$\mathrm{Na}$ escala adotada, além dos padrões de formas de relevo semelhantes, também foram representados alguns elementos morfoestruturais e morfodinâmicos característicos de cada um dos dois conjuntos de compartimentos geomorfológicos, que evoluíram em escalas de tempo dissimétricas e formaram uma paisagem com relevo escalonado em termos de altimetria.

Num primeiro conjunto, sustentado por litologia resistente dissecado majoritariamente conforme os padrões estruturais, foi possível representar processos erosivos remontantes que têm conduzido capturas fluviais, reorganizadoras das formas de relevo e da dinâmica erosiva e deposicional regionais, além da influência tectônica no alinhamento de cristas e da elevada resistência litológica na elaboração de áreas de topos aguçados e de linhas de cumeada extensas. Os padrões morfométricos em interação com as demais características naturais, principalmente climáticas, indicam ambientes com predomínio de alta suscetibilidade à erosão e movimentos gravitacionais de massa, importantes do ponto de vista do uso e ocupação e do planejamento da paisagem por frequentemente converterem-se em problemas socioambientais.

No outro conjunto, cuja deposição em termos genéricos se instalou em áreas tectonicamente rebaixadas e foi conduzida por fatores exógenos, puderam ser representados elementos da dinâmica litorânea resultantes das transgressões-regressões marinhas, registradas nas cristas de praias ou mesmo nos pontões, e também da dinâmica eólica, nos sedimentos remobilizados. Neste caso, os padrões

$\begin{array}{lllll}\text { Caminhos de Geografia } & \text { Uberlândia-MG } & \text { v. 22, n. } 83 & \text { out./2021 } & \text { p. 219-239 }\end{array}$


morfométricos e as demais características naturais indicam ambientes com trechos de alta suscetibilidade à inundações e alagamentos, igualmente importantes nos termos supracitados.

Pela visão integradora, a cartografia geomorfológica possibilitou compreender a configuração do relevo na região. As reflexões propostas podem colaborar com trabalhos de natureza semelhante e os materiais gerados podem contribuir com o avanço do conhecimento da Geomorfologia ou mesmo de outras disciplinas e pesquisas que tratem da paisagem da Baixada Santista em seu aspecto natural e/ou socioambiental.

\section{AGRADECIMENTOS}

Os autores agradecem à CAPES pelo apoio via concessão de uma bolsa de doutorado e à UNICAMP e ao Instituto de Geociências pelo apoio e infraestrutura. Ao NEAL (Núcleo de Estudos Ambientais e Litorâneos da Universidade Estadual de Campinas) pela cessão do banco de dados digitais das cartas topográficas 1:50.000 e à AGEM pela disponibilização de acervo imagético e cartográfico.

\section{REFERÊNCIAS}

AB'SABER, A. N. A evolução geomorfológica. In: AZEVEDO, A. (Coord.). A Baixada Santista: Aspectos Geográficos. Aspectos Físicos. Vol. I. São Paulo: Editora da Universidade de São Paulo, 1965.

ALMEIDA, F. F. M. The system of continental rifts bordering the Santos Basin, Brazil. Anais da Academia Brasileira de Ciências (suplemento), v. 48, 1976. https://doi.org/10.25249/0375-7536.1998135150

ALMEIDA, F. F. M.; CARNEIRO, C. D. R. Origem e evolução da Serra do Mar. Revista Brasileira de Geociências. v. 28, n. 2., p.135-150, 1998.

BOTELHO, R. G. M.; PELECH, A. A. Do mapeamento geomorfológico do IBGE a um Sistema Brasileiro de Classificação do Relevo. Revista Brasileira de Geografia, v. 64, n. 1, p. 183-201, 2019. https://doi.org/10.21579/issn.2526-0375 2019 n1 183-201

CASSETI, V. Geomorfologia. Rio de Janeiro: IBGE, 2005.

CHRISTOFOLETTI, A. Geomorfologia Fluvial: o canal fluvial. São Paulo: Edgar Blücher, 1981.

CPRM - Companhia de Pesquisa de Recursos Minerais. Mapa Geológico do Estado de São Paulo. Folha única, escala 1:750.000, 2006. Disponível em: http:/www.cprm.gov.br/publique/Geologia/GeologiaBasica/Cartografia-Geologica-Regional-624.html. Acesso em: 10 dez. 2018.

ESA - European Space Agency; USGS - United States Geological Survey. Imagens multiespectrais Sentinel 2B sensor MSI: nível de processamento 1C, 2018. Disponível em: https://earthexplorer.usgs.gov. Acesso em: 05 nov. 2018.

ESRI - Environmental Systems Research Institute. ARCGIS Desktop 10.6, 2018.

GIANNINI, P. C. F. Sedimentação Quaternária na Planície Costeira de Peruíbe-Itanhaém. Dissertação (Mestrado em Geologia) - São Paulo: USP. 1987.

GIGLIOTTI, M. S.; OLIVEIRA, R. C. Zoneamento Geoambiental da Região Metropolitana da Baixada Santista. In: CUNHA, C. L.; OLIVEIRA, R. C. Baixada Santista: uma contribuição à análise geoambiental. São Paulo: Unesp Digital, 2015. p. 35-60.

GIGLIOTTI, M. S. Zoneamento Geoambiental da Região da Baixada Santista-SP como subsídio ao uso e ocupação das terras. Dissertação (Mestrado em Geografia) - Campinas: UNICAMP. 2010.

HASUI, Y. A grande colisão pré-cambriana do sudeste brasileiro e a estruturação regional. Geociências, v. 29, n. 2, p. 141-169, 2010.

IBGE - Instituto Brasileiro de Geografia e Estatística. Cartas topográficas. Escala: 1:50.000. Folha Rio São Lourencinho SG-23-V-A-II-2, Pedro de Toledo SG-23-V-A-II-4. 1973. 
Cartas topográficas. Escala: 1:50.000. Folha Salesópolis SF-23-Y-D-V-3, Salesópolis SF-23-YD-V-1, Mogi das Cruzes SF-23-Y-D-IV-2, Santos SF-23-Y-D-IV-3, Santos SG-23-V-B-I-1, Embu-Guaçú SF-23-Y-C-VI-3, Riacho Grande SF-23-Y-C-VI-4. 1984.

Climas do Brasil. 2002. Disponível em: https://www.ibge.gov.br/geociencias/informacoesambientais/climatologia/15817-clima.html?=\&t=acesso-ao-produto. Acesso em: 10 dez. 2019.

Manual Técnico de Geomorfologia. 2 ed. Rio de Janeiro: IBGE, 2009.

Malhas digitais municipais. 2015. Disponível em: https://mapas.ibge.gov.br/bases-ereferenciais/bases-cartograficas/malhas-digitais. Acesso em: 05 jun. 2019.

. Base temática vetorial 1:250.000 - Brasil - Geomorfologia. Catálogo de metadados. Rio de Janeiro, 2018. Metadados de: amostragem em campo, área, forma de relevo linear e forma de relevo pontual. Disponível em: http://www.metadados.geo.ibge.gov.br. Acesso em: 05 ago. 2019.

IGC - Instituto Geográfico e Cartográfico do Estado de São Paulo. Cartas Topográficas. Escala 1:50.000. Folha Mongaguá SG-23-V-A-III-2, Bertioga SF-23-Y-D-IV-4. 1971. III-3. 1972.

Cartas Topográficas. Escala 1:50.000. Folha Itanhaém SG-23-V-A-III-1, Itanhaém SG-23-V-A-

; AGEM - Agência Metropolitana da Baixada Santista. Sistema Cartográfico Metropolitano da Baixada Santista: cartas topográficas e ortofotocartas. 128 folhas de 1022 a 6346, escala 1:10.000, 2002. Catálogo disponível em: https://www.agem.sp.gov.br/?page_id=1130. Acesso em: 01 dez. 2019.

LIBAULT, A. Os quatro níveis da pesquisa geográfica. Métodos em Questão, IGEOG-USP, 1971.

LIPORACI, S. R.; ROHM, S. A.; PEDRO, F. G.; CEREDA JUNIOR, A. Comparação entre Diferentes Técnicas Digitais para Elaboração do Modelo Digital do Terreno e da Carta de Declividades, com Aplicação em Mapeamento Geológico-Geotécnico e Análise Ambiental. Holos Environment, v. 3, n. 2, p. 85-102, 2003. https://doi.org/10.14295/holos.v3i2.1129

MARQUES NETO, R.; FERRARO, B. V. Cartografia geomorfológica regional e Morfogênese: Contribuições metodológicas. Revista Brasileira de Geomorfologia, v. 19, n. 2, p. 267-281, 2018. https://doi.org/10.20502/rbg.v19i2.1267

METI - Messaging Extraterrestrial Intelligence; NASA - National Aeronautics and Space Administration. ASTER GDEM: Global Digital Elevation Model. 2011. Disponível em: https://earthexplorer.usgs.gov/. Acesso em: 01 nov. 2019.

PELECH, A. A.; NUNES, B. T. A.; GATTO, L. C. S.; BOTELHO, R. G. M. Considerações sobre o mapeamento geomorfológico do território brasileiro: algumas abordagens na representação regional. Revista Brasileira de Geomorfologia, v. 30, n. 3, p. 681-690, 2019. https://doi.org/10.20502/rbg.v20i3.1565

PENTEADO, M. M. Fundamentos de Geomorfologia. Rio de Janeiro: IBGE, 1983.

PROJETO MAPBIOMAS. Coleção 4.0 da Série Anual de Mapas de Cobertura e Uso de Solo do Brasil. 2018. Disponível em: http://mapbiomas.org/. Acesso em: 05 set. 2019.

QGIS Development Team. QGIS User Guide, Long Term Release 2.18: QGIS Project, 2016. Disponível em: https://www.qgis.org/en/site/. Acesso em: 02 fev. 2018.

RIBEIRO, R. R. Evolução geomorfológica da Serra de Cubatão, em São Paulo. Dissertação (Mestrado em Geologia) - São Paulo: USP. 2003.

ROSS, J. L. S. Geomorfologia: ambiente e planejamento. 9 ed. São Paulo: Contexto, 2012.

ROSSI, M. Mapa pedológico do Estado de São Paulo: revisado e ampliado. Secretaria do Meio Ambiente do Estado de São Paulo. São Paulo: Instituto Florestal, 2017.

SÃO PAULO (Estado). Inventário florestal da vegetação natural do Estado de São Paulo. Secretaria do Meio Ambiente do Estado de São Paulo. Instituto Florestal: Imprensa Oficial, 2005. 
SILVEIRA, J. D. Morfologia do litoral. In: Azevedo, A. (ed). Brasil: a terra e o homem. Vol. I. São Paulo: Companhia Editora Nacional, 1964.

SOUZA, C. R. G. The Bertioga Coastal plain: an example of Morphotectonic Evolution. In: VIERA, B. C.; SALGADO, A. A. R.; SANTOS, L. J. C. (eds.). Landscape and Landforms of Brazil, Word Geomorphological Landscapes. Springer Science+Business Media Dordrecht: Springer Netherlands. 2015.

SUGUIO, K.; MARTIN, L. Formações quaternárias marinhas do litoral paulista e sul-fluminense. Internacional Symposium on Coastal Evolution in the Quaternary. São Paulo: Universidade de São Paulo, p. 1-52, 1978.

TESSLER, M. G.; GOYA, S. C.; YOSHIKAWA, P. S.; HURTADO, S. N. Erosão e progradação no litoral brasileiro: São Paulo. In: MUEHE, D. (org.). Erosão e progradação no litoral brasileiro. Brasília: MMA, 2006.

Recebido em: $28 / 07 / 2020$

Aceito para publicação em: 03/12/2020 